\title{
Den kirkelige anskuelse som svar til Karon: Randbemærkninger til tre sømandssange af Grundtvig
}

\author{
Af Aage Schiøler
}

Ud fra motivfællesskabet $\mathrm{i}$ de tre tekster $\mathrm{A}, \mathrm{B}$ og $\mathrm{C}$, aftrykt $\mathrm{i}$ afsnittet "Kildetekster", Grundtvigs genbrug i øvrigt af motiver og tidligere tekster samt det ønskelige i en teologisk tilgang til tekst B, søges digtet "Gammel nok jeg nu er blevet" placeret inden for Grundtvigs anskuelser om menneskeliv og kristendom og som led i forfatterskabets lange sammenhæng, også med henblik på nøjere at præcisere Karon-mytens funktion i digtets sammenhæng og at tydeliggøre digtets særpræg som svar i en eksistentielt afgørende situation.

\section{Indledning}

I 1990'erne blev ordforråd, billeddannelse og tankegods i Grundtvigs sidste digt "Gammel nok jeg nu er blevet" (GSV V, 350; GrSt 1994, 107) drøftet i en række afhandlinger i GrSt. Drøftelsen blev sat i gang af Fl. Lundgreen-Nielsens argumentation for et slægtskab med den græske myte om Karon, der færger de døde til Hades, og hans syn på digtet "som en forvendt Karon-myte, hvor den antikke færgekarl er erstattet af Guds ånd, hans stage af Gudsordets kompas". Det sker på baggrund af en forbilledlig tekstkritisk analyse af håndskriftet i Grundtvigarkivet, en analyse der også, så vidt det vel overhovedet er gørligt, sikrer læsemåden "Sjæle-Færge-Stavnen" i slutningen af digtets tredje strofe (Lundgreen-Nielsen 1994, 107-19). Allerede tidligere har Lundgreen-Nielsen set dette hapax legomenon som "Grundtvigs positive omdigtning af Karons båd", mens kristne motiver for ham først dukker op i de følgende strofer (Thodberg 1983, 40-41).

Også Uffe Hansen er opmærksom på forbindelsen til græsk mytologi (1966, III, 350; jf. GSV VI/3, 497, sp. 2). William Michelsen præciserer digtets situation som fællesmenneskeligt eksistensanliggende, henviser rigtigt, men uden nærmere argumentation til kirken som et skib og foreslår bibelske belæg for digtets udsagn om gudsnærvær (1995, 102-7. 1999, 226-27). Merete Bøye understreger faremomentet $\mathrm{i}$ havmetaforen gennem henvisning til angelsaksisk digtning og passager i nogle prædikener af Grundtvig over teksten til 4. søndag efter helligtrekonger, Matt 8,23-27, om "Stormen på Søen" 
(1998, 128-36). Disse arbejder giver et grundigt indblik $\mathrm{i}$ det sprogmateriale, digteren arbejder med, men belyser kun delvist, hvordan det er indarbejdet $\mathrm{i}$ hans kristne tankeverden. Bent Noack (1993, 102-12) giver en forbilledligt klar gennemgang af digtets forkyndelse. Det forhold, at den hos Grundtvig er indlejret i og bæres af et historisk forløb og de fortællinger, dette afføder, er ikke med i synsfeltet, antagelig fordi det ville sprænge både artiklens rammer og sammenhængen, den er placeret $i$.

I efteråret 2002 stiftede jeg i forbindelse med læsning af Uffe Hansens Grundtvigs Salmedigtning bekendtskab med sangen "KirkeSkibet" fra ca. 1834, der i første udkast har overskriften "Menneskens Liv" (GSV III, 124; VI/2, 216, sp. 2). Sangen har åbenlyst motivællesskab med "Bortgangskvæde", som jeg med Holger Begtrup kalder Grundtvigs sidste digt (US X, 576), ${ }^{1}$ men har tilsyneladende ikke tiltrukket sig opmærksomhed i ovennævnte drøftelse. Også de sidste strofer af "Aandelig Fiskervise", der blev trykt i Nordisk Kirketidende i 1838, rummer motivsammenfald med et par passager i "Bortgangskvæde" og har derfor krav på opmærksomhed (GSV II, 74, her med titlen "Simon Peters Kald").

Fællesmotiverne falder $\mathrm{i}$ to grupper. Den første er knyttet til søfarten og omfatter sejladsen på havet og selve skibet. Den anden inddrager de tre elementer, der hos Grundtvig er bestemmende for hans opfattelse af kristendommen som på én gang historisk fænomen og eksistentiel tiltale, nemlig forkyndelse/sang, dåb og nadver.

"Kirkeskibet" er ganske vist mere end en menneskealder ældre end "Bortgangskvæde", og Grundtvig selv udgav ikke de to digte, men det tidlige digt overlod han i 1870 til Ernst Trier, som bad om stof til et sanghæfte, der blev brugt i Ernst Triers lille gaveskrift til Refsnæs Friskole (GSV VI/2, 216; Hansen 1937, I 212). Både "Kirkeskibet" og "Aandelig Fiskervise" kom med i Sangvoerk til den Danske KirkeSkole samme år, og Grundtvig blev således i sin høje alder mindet om disse tidlige bidrag til manddomstidens bestræbelser på at forny den danske menighedssang.

To andre åbenlyse tilbagegreb til tidligere digte kan belyse sagen. Mest kendt er tildigtningen i 1872 af fire linjer til et uddrag fra “Aabent Brev til mine Børn" fra 1837 (US VIII, 187), så sangen "Et jævnt og muntert, virksomt Liv paa Jord" blev resultatet. Også her er Ernst Trier initiativtager. Det andet tilfælde er tilføjelsen fra august 1872 af en ny strofe til digtet "Den hellige, almindelige Kirke" fra 1840'erne (GSV IV, 23; VI/2, 278-9. Hansen 1951, II, 159-60). På baggrund af denne brug af tilbagegreb til tidligere digte i tiden lige før tilblivelsen af "Bortgangskvæde" kombineret med det forhold, at Grundtvig arbejdede med de samme eksistensforhold hele livet 
igennem og $\mathrm{i}$ hvert fald fra 1811 med bevidst insisteren på en kristen synsvinkel, synes sammenfaldet af motiver i "Kirke-Skibet", herefter A, "Bortgangskvæde", herefter B, og "Aandelig Fiskervise", herefter C, værd at se nærmere på.

Artiklen indledes med en afdækning af de enkelte motiver og deres særpræg i hvert af de tre digte, idet der også inddrages materiale, især fra GSV, til belysning af Grundtvigs anvendelse af genbrug og tilbagegreb i forbindelse med disse motiver. ${ }^{2}$ Derpå illustreres det dødsmotiv, der er den direkte anledning til $\mathrm{B}$, og de negative og positive sprogudtryk, det foranlediger, modstilles med henblik på formulering af et samlende indtryk. Endelig sammenholdes de vundne indsigter med grundstrukturen i Grundtvigs kristendomsforståelse for at belyse karakteren af digtets stillingtagen til det rejste eksistensspørgsmål. Afhandlingen slutter med et forsøg på at formulere svarets muligheder som nutidigt udsagn.

\section{Fallesmotiver fra søfarten}

Denne første gruppe omfatter sejladsen med dens forløb, dens mål og havets karakter, herunder havet som trussel, samt selve skibet. Teksterne nærlæses med henblik på at fastlægge det omfang og det særpræg, motiverne, især havet og skibet, har i de enkelte tekster. Herudfra søges fartøjets funktion og karakter i forhold til Karons pram nærmere præciseret.

\subsection{Forste fællesmotiver}

(a) Rejsens forløb er i A en langstrakt affære. Digtet begynder i str. 1 med det gamle billede af menneskelivet som et skib på oprørt hav, jf. digtets titel i første udkast ( $G S V \mathrm{VI} / 2,216$, sp. 2). ${ }^{3}$ Det er kendt af mange fra Ambrosius Stubs "Hvad vindes ved Verdens vidtløftige Hav!" (Stub, nr. 27). Flere danske eksempler forekommer hos Lundgreen-Nielsen 1994, 112-14. Hos Grundtvig fornyes skibet i str. 5 , så menneskelivet tilføres den mulighed, at det kan leves som kristenliv, "i Jesu Navn”, på basis af dåben (str. 6-7) og opretholdt af nadveren (str. 11). Skibet er blevet kirkeskibet. Det lander omsider "paa den Kyst, / Hvor Livet har sin Kilde" (str. 12,2-3). Med til fornyelsen hører også, at man kan stå på undervejs: "Komme hver da, som har Lyst" (str. 12,1), til forskel fra, at vi ellers kun véd "to Havne / Bekiendte af Navne, / Den eene vor Vugge, den anden vor Grav", for nu at blive i Stubs eminente brug af skibsbilledet ("Livet som en Seylads", str. 1,3-4). 
I B er beskrivelsen af rejsen drastisk beskåret. Udformningen kalder fortællingen om "Stormen på Søen" (Matt 8,23-27) frem i erindringen. Her bringer Jesus øjeblikkeligt søen til ro, da han bliver vækket og derved nærværende. Men navnlig fortællingen om Vandringen på Søen, som den gengives i Johs 6,16-21, pådrager sig opmærksomhed. Først beskrives situationen i båden således: "Det var allerede blevet mørkt, og Jesus var endnu ikke kommet. Søen var i oprør, for der blæste en hård vind" (v. 17b-18). B har også mørket (uglen som skumringens fugl, men ikke kun det; se senere), det oprørte hav og den voldsomme vind. Efter at Jesus er dukket op, hedder det endvidere: "Så ville de tage ham op i båden, og straks var båden fremme ved den søbred, de var på vej til” (v. 21). Tempoet og temaet er det samme som i "Brat sig aabner Himmel-Havnen" (B, str. 3).

$\mathrm{C}$ har udtryk for en lignende umiddelbar og tidsubestemt tilgang til Gud, "Hvor frit de evig gaae ind og ud, / Og Glæden dem altid følger!" (str. 8,6-7, mine fremhævelser).

(b) Rejsens mål beskrives næsten enslydende i de tre digte. I A hedder det "Himmel-Havn" og "Fredens Havn" (str. 5 og 7), "Livets faste Land" og "... den Kyst, / Hvor Livet har sin Kilde" (str. 3 og 12). B bruger betegnelserne "Himmel-Havnen" og "Guds-Bordet" (str. 3 og 5), men inddrager også det oprindelige livets land: "Paradis", og det endegyldige: "Evigheden" (str. 3 og 4). C taler blot om "Livets Kilde" og om "Gud" (str. 8).

Fælles for teksterne er, at rejsens mål er adskilt fra Verden. I A ligger det hav, der skal besejles, mellem "denne Verdens $\emptyset$ " og destinationen (str. 3). B bruger blot det barske "Naar med denne Verden brydes" (str. 5). Formuleringerne i C: "Fra Verden føre vi dem til Gud" og "Verden de maae forsage" (str. 8 og 9) angiver det samme anliggende med udtryk, der falder mere konventionelt og derfor umiddelbart kan lyde mindre kategoriske, men ved nærmere eftertanke næppe er det. Bag ved str. 6,5-7, kan der ligge erindring om Grundtvigs eget afkald på virket som litterat og historiker, da han tiltrådte som personel kapellan hos sin far i 1811. Se Chr. Thodbergs påvisning af den betydning, karriereskiftet havde, der kan aflæses af hans prædikener over Luk 5,1-11, Peters Fiskedræt (Thodberg 1989, 242-95).

(c) Det farlige hav er åbenlyst til stede i både A og B, men udtrykkene for det er stærkt intensiveret i B. Her er havet blevet til "det store, vilde Hav" og "Stormene er frygtelige" (str. 1 og 2). A har de mere rolige udtryk "Strøm og Storm og blinde Skiær", der nok drejer sig om det åbne hav over for de indre farvande, men i denne egenskab også er 
mere truende. Det er stedet, "Hvor ranke Bølger skumme", og da "rank" i den tids dansk rækker i retning af "stejl", er de aldeles ikke ufarlige (str. 1 og 3). Der er ingen farvandsefterretninger i C.

Den fare, billederne af rejsens risici dækker over, formuleres i A gennem en advarsel om døden i den lumske skikkelse af en overdækket grav, en ulvefælde, som der advares imod af "Fugle-Sang i Skoven" (str. 4). Her over for står i B den direkte trussel: "Bundløs der er Undergangen", og nu er det uglen, nattens jæger med de tyste vingeslag, der giver lyd fra sig (str. 2). Denne uglesang er en art antisang; den advarer ikke, den truer direkte med død og ulykke. I C antydes faremotivet med talen om "Hjerte-Dybet (...) / Hvor timeligt ei kan bunde" (str. 9).

\subsection{Havet i nogle Grundtvig-salmer}

\section{Seks eksempler}

Havet som farligt har Grundtvig inddigtet i den afgørende strofe i sin gengivelse fra 1853-55 af Paul Gerhardts "Befiel Du deine Wege":

Da allerstørst var Nøden,

Du spared ei din Søn, For Syndere fra Døden

At bane Udvei skiøn;

Dermed paa Hjælp af Naade

Du sikkert Pant os gav,

Hvor grumt saa end mon fraade

Det vilde Verdenshav

(GSV IV, 409,5. DDS-2003, 38,5)

Spørger man om baggrunden for dette for Gerhardts tekst helt fremmede billede, kan svaret søges $\mathrm{i}$ de følgende tre strofer $\mathrm{i}$ håndskriftet, hvoraf de to sidste ikke er med i $G S V$ IV, men gengives i $G S V \mathrm{VI} / 2$, 362, og i Malling IV, 286, sp. 2. Her vender digteren tilbage til landjorden, hvor Gerhardt færdes. Da jeg ser disse tre strofer som en trinitarisk opbygget enhed med kristologisk substrat, gengiver jeg dem her i sammenhæng:

Du Vei har allesteder,

Dig alt tilrede staaer,

Og du i Lys dig klæder,

Det skinner hvor du gaaer,

Saavidt som Stjerner tindre,

Kan dine Arme naae,

Trods hvem det vil forhindre, 
Du hjælper dine Smaa.

(GSV IV, 409, 6. Malling IV, 286, str. 6)

Om alle Jordens Bjerge

Og hele Helveds Hær

Sig satte til Modværge

De fik dog en Ufærd;

Det er ei nok, du seirer

Med evigt Heltenavn,

Al Modstand Du henveirer

Som Vinden Straa og Avn!

Lyksalig da sig skatte

Guds hele Børne-Flok,

Som føle kan og fatte,

Guds Naade os er nok!

I deres Mund er Psalmen

Indlagt til evig Priis,

Til deres Haand er Palmen

Opgroet i Paradis!

(GSV VI/2, 362, sp. 2ø; Malling IV, 286, str. 7-8)

I den første af disse tre strofer forekommer "Lys", en af fællesbetegnelserne for Skaber og Frelser (1 Johs 1,5; Johs 8,12) med udgangspunkt i skabelsessalmen SI 104, v. 2a: "du hyller dig i lys som en kappe", der lægger hovedvægten på Skaberens forsynsvirke, her med henvisning til "dine Smaa", der tydeligvis peger hen på Matt 18, $1-4$, hvor Jesus går i brechen for "disse små".

Den sidste strofe henviser til Guds nådes tilstrækkelighed, et udpræget kristologisk udsagn (2 Kor 12,1-10), men her indlejret $i$ en kollektiv ramme: "Guds hele Børne-Flok", som svarer til den menighed, der skabes ved Helligånden, og hvor sang til Guds ære afrunder strofen og dermed det trinitariske adsnit af salmen.

Den mellemste strofe, Kristus-strofen, taler nok om det samme "du" som den første strofe, men gennem sejrherremotivet forskydes vægten i retning af Gud som Frelser. Selv om motivernes rækkefølge er en anden, kan den ses som en parallel til Martin Luthers kristologiske tolkning af Sl 46 i str. 2-3 af "Ein feste burg ist unser Gott" (D. Martin Luthers Werke, 35. Band, Weimar, 1923, 455-56, nr. 26). Grundtvig begynder sin strofe med "hele Helveds Hær", som hos Luther kommer lidt senere: "Und wenn die Welt vol Teuffel wer (...)" (str. 3,1), og slutter med henvisningen til sejrherrens "Heltenavn", som Luther lægger ud med og udtrykkeligt nævner:

Es streit für uns der rechte man,

Den Gott (hat) selbs erkoren,

Fragstu wer der ist?

Er heist Jhesus Christ, 
Der Herr Zebaoth,

Und ist kein ander Gott,

Das felt mus er behalten,

(str. 2, 3-8)

Karakteristisk for Grundtvigs udformning er, at han i denne strofe om Sønnen reflekterer tilbage til strofen forud for det trinitariske afsnit, der også talte om Sønnen, men ikke udfoldede, kun fastslog, dennes virke. Sammentænkningen af de to strofer sker gennem en kristologisk brug af Es 17,12-13:

Ve os! Der er larm af mange folkeslag, de larmer, som havene larmer;

der er bulder fra folkene, de buldrer, som de vældige vande buldrer.

Men han truer ad dem, så de flygter bort;

de jages af vinden som avner på bjergene, som kugletidsler jages af hvirvelvinden.

Sammenfaldet af "hav" og "avner" hos Grundtvig og Esajas gør det klart, at havet som truende i "Paa alle dine Veie" er bibelsk inspireret. Dertil har det hos Grundtvig samme direkte kontrast til Jesusskikkelsen som i fortællingerne om underne på Genesaret sø, og det truende hav er aldeles uden henvisning til græsk mytologi. Ifølge Malling IV, 287, sp. 2, siger Høirup om havstrofen: "Mod dette vers styrer salmen fra begyndelsen. Saadan sætter Grundtvig Kristusdogmet ind som grundlag for forsynstroen".

I den lidt tidligere salme "Han, som har hjulpet hidindtil" finder vi i 1845-1850 følgende parallelføring af et praktisk og et personligt trusselsbillede:

Den øde Ørk, det vilde Hav,

Den haarde Vinter-Kulde,

over for:

Den dybe Sorg, den mørke Grav,

De Kiære under Mulde

(GSV IV, 208, 2. DDS-2003, 33)

Også her associerer "det vilde Hav" til døden som en trussel, der følger os livet igennem, men kan afværges ved Guds almagt. Det fremgår af strofens slutlinjer, hvis billede omslutter både mennesket selv som historisk/psykisk eksistens og det fysiske skaberværk, det færdes i og er en del af: 
For alt hos Gud er gode Raad,

Til Frydesang han vender Graad,

Saa let som Vind og Vove.

(GSV IV, 208, 2. DDS-2003, 33)

Derudover er der grund til at bemærke, at frisættelsen formuleres med elementer fra tempel-terminologien, som Grundtvig tager i anvendelse ved formuleringen af sit dåbssyn:

Da aabner sig, som aldrig før

Guds-Rigets Port, Guds-Husets Dør

Og Livets Kilder alle.

(ibid., str. 3)

som klart henviser til S1 24,7.9, og til Sl 87,7, og som indbefatter menneskets mulighed for at bruge "salmens tonestige":

Saa faaer vor Sjæl dog Vinger,

Saa den med Ordet evigungt

Sig let til Himlen svinger.

(str. 4)

Den nærmestliggende baggrund for trusselsbilledet i denne salme er fortællingerne om overgangen over Det Røde Hav og Vandringen i Ørkenen i 2 Mos 14-18.

I 1843-45 udarbejdede Grundtvig i flere forløb salmen "At sige Verden ret Farvel". Her finder vi disse linjer:

Hvor tit hos dig end Trøst jeg fandt,

Naar Hjertet skjalv og Graaden randt,

Og Verdens Bølger bruste...

(GSV IV, 95, 2. DDS-2003, 538)

hvor "Verdens Bølger" uanset strofens skiftende plads og det ændrede ordvalg, inden digtet finder sin endelige form, fastholdes som den tredje og sidste fare, digteren har fundet trøst for hos Jesus. Det må også noteres, at denne trøst efter forslag om flere ønskede muligheder finder sin endelige form i Frelserens komme i Ordet:

Kom, som du vil! jeg veed det vist,

Du har selv sagt, at her og hist

Du kiendes vil paa Røsten;

Den Røst, hvorved, trods Verdens Larm,

Os Hjertet brænde kan i Barm,

Og smelte hen i Trøsten!

(str. 7) 
hvor "Verdens Larm" er helt analog med dens brusende bølger. (Hansen 1951, II, 145-55, og Holm 1997, 148-84, orienterer om teksthistorien).

Her er ingen klare indikationer om baggrunden for at bruge bølgerne som trussel, selv om Es 17,12 og Sl 42,8 kan komme på tale både i str. 2 og str. 7. I den sidste må situationen ses ud fra sammenhængen med str. 6, der mest tænkeligt er udsprunget af Matt 14,24-27 (Stevns 1950, 69). Trøsten er under alle omstændigheder tydelig nok og ikke kun begrænset til livets afslutning, jf. "Hvor tit (...)".

Fra 1834 har vi som nævnt "Kirke-Skibet", der er truet af havets bølger livet igennem (GSV III, 124), og mest sandsynligt via Kingos "Hvad er det for en Snekke" (Ths. Kingos Samlede Skrifter IV, 210, København, 1975) går tilbage til Matt 8,23-27, fortællingen om "Stormen på Søen".

I 1828 møder vi det lange digt "Syndfloden" (GSV II, 8), hvor konsekvenserne af truslens dødelige karakter har en form, der er barok på grænsen til det groteske:

Da Orme-Hæren

Med Kuld paa Kuld

Var stolt af Æren

At boe i Muld,

Da holdt de Gilde

Saa høit de vilde,

Da fik de Huld!

Sig Kæmper høie,

I Konge-Dyb,

Da maatte bøie

For Madik-Tyv!

(str. 31-32)

men sammenhængen, hvori disse konsekvenser fremføres, er entydigt bibelsk.

Et lige så tydeligt bibelsk grundlag har vi i Grundtvigs gengivelse på rimede strofer fra 1810-11 af S1 42-43: "Som tørstige Hjort monne skrige ..." (GSV III, 35. DDS-2003, 410). Her bliver: "Afgrund raaber til afgrund for dine renders skyld; alle dine (vand)vover og dine bølger gik over mig" (Sl 42, 8; AO 1740/1819) ${ }^{4}$ til:

Alt bryde de Bølger og Vover,

Og medens du tøver og sover 
De lukke sig over min Sjæl.

(str. 4)

Hjælpen er endnu fremtidig, men som i trinitetsstroferne $\mathrm{i}$ "Paa alle dine Veie" og str. 4 i "Han, som har hjulpet hidindtil" er den frelstes takkesang til Gud inkluderet i hjælpens udfald:

Engang skal den Morgen oprinde,

Da frelst du saa glad udi Sinde

Skal takke og love din Gud.

Hans Lys og hans Sandhed skal føre

Mig op til hans Tempel i Fred,

Der Ordet mit Hjerte skal røre

Og glemme jeg skal, hvad jeg leed;

Ja, selv skal jeg røre min Tunge

Til Psalmer for Herren at sjunge

Til Lov og til Pris for min Gud.

(str. 6-7)

Takkesangen og dens tilknytning til templet dukker tilmed, som nævnt ovenfor, op igen i "Han, som har hjulpet hidindtil" (GS IV, 208, 2,7-8; 3,5-7; 4,1-4. DDS-2003, 33). Udtrykket "Min Sjæl, hvi bruser du da saa" (str. 6,1) synes tilmed oven i købet at pege tilbage på SL 42,6.11; 43,5, måske endda i erindring om "Som tørstige Hjort...", str. 6,1-2:

Dog, hvi vil, min Sjæl, du forsage?

Hvi bøies, hvi bruser du saa?

(GSV III, 35, 6. DDS-2003, 410)

Med jævne mellemrum og i forskellige kombinationer optræder havet altså, når Grundtvig ser sig stående over for eller af anden grund skal give udtryk for dødens trussel mod livet. Når det, som i "At sige Verden ret Farvel", bliver den personlige død, der trænger sig på, optræder Frelseren "Jesus Kristus", som dens modpol, repræsenteret af Ordet.

\section{Bibelske billeder}

I billedvalget i de fremdragne tekster er der en tydelig inspiration fra GT, et forhold, som falder naturligt, når det betænkes, at Grundtvig var dybt fortrolig med Bibelen og i hvert fald efter 1810-11 anså dens billedsprog for en helt enestående tilgang til tolkningen af mennesket som et væsen med historisk tilværelse. Jeg anser derfor GT som primær-kilde til hans brug af det truende hav som negativitetens repræsentant, ikke mindst fordi de ovennævnte eksempler kan suppleres med flere andre. Nævnes kan Det røde Hav fra udvandringsfortællingerne i 2 Mos 14,1-15, 21, brugt i en prædiken påskedag 1840, der kan findes på netadressen: 
http://grundtvigsiden.homepage.dk/praedk/paaske40.htm, ${ }^{5}$ og Jonas' bog med "en stærk storm over havet" (Jon 1,4) samt flere nødråb i Davids Salmer, for eksempel Sl 18,5-7 + 17-20, Sl 69,2-3, og Sl 130,1b-2). Et yderligere indicium for, at Grundtvig i brugen af havet som trussel er inspireret af GT, er, at dette hav hos ham lejlighedsvis sammenstilles med ørkenen. Sidst i 1840'erne som nævnt "Den øde Ørk, det vilde Hav" (GSV IV, 208, 2. DDS-2003, 33), sidst i 1850'erne:

\section{Just for de Smaa}

Er Løngangs-Stien lavet,

Til trygt at gaae

I Ørken og paa Havet, (GSV V, 162, 4. DDS-200, 379)

Denne konstellations plads i GT's tankegang er tydeligt demonstreret af Pedersen (1920, 362n - 371m).

I NT optræder havbilledet i forbindelse med underfortællingerne fra Genesaret sø. Vender vi specielt tilbage til det truende hav i Johs 6,16-21, kunne afsnittet ud fra indlejringen i Johs 6,1-71, ses som modlegende til Karon-myten på samme måde, som nogle forestiller sig fortællingen om brylluppet i Kana i Johs 2,1-12, som modlegende til Dionysos-myten, der også indeholder motivet om forvandling af vand til vin (Bultmann 1959, 83). Der er en række fællestræk, som kan støtte denne parallel. Jesu afvisning af Maria i 2,4 kan ses som aktiv analogi til hans passive reaktion i 6,15: "han trak sig (...) tilbage (...) helt alene". Afskærmningen fra publikum søger begge steder at forhindre den falske forståelse af underet: at imødekommelsen af menneskets fysiske behov udtømmer handlingens hensigt. Desuden følges Jesu reaktion i begge tilfælde op af en hentydning til døden: "Min time er endnu ikke kommet" $(2,4 b)$ og den oprørte sø $(6,18)$. Disciplenes tro $(2,11)$ og Peters bekendelse $(6,68)$ minder også meget om hinanden. Endelig har begge fortællinger Kapernaum som endestation $(2,12$ og 6,59$)$.

Væsentligere end forholdet til Johs 2,1-12, og til Karon-myten er det dog at fastholde forbindelsen til GT. Så bliver det tydeligt, at den oprørte sø i Johs 6,18 ikke optræder som en mere eller mindre vanskeligt passabel grænseegn til noget ukendt, men som en repræsentant for døden som aktivt ødelæggende magt. Den frelsende Jesusskikkelse bliver modpolen til denne ødelæggende virksomhed, og selve sø-underet kommer til at fremstå som mere end en art transportmodul mellem en øde egn og den beboede by. Det bliver et integreret led i bevægelsen fra død til liv, som i Johs også beskrives af bevægelsen fra løgn, in casu Jesus som verdslig hersker $(6,15)$, til 
sandhed: Jesus som Livets Brød (6,35). For Grundtvigs vedkommende svarer denne brug af det truende hav også til hans modvilje mod at se døden som blot et efterlivs-fænomen. I ordskiftet med Marheinecke ser han den således som aktør i menneskelivet (Thaning 1963, 749, jf. 642 og 654 , note 25 ).

\section{Opsamling om havet}

Hav, bølger, og strøm med forskellig grad af farlighed bruges af Grundtvig som billede på tidens omtumlede forløb. Ud over litterære forlæg som Verdens Hav kan hans optagethed af den danske flådes bedrifter og tab, aktualiseret af hans bekendtskab med Peter Willemoes, og hans efter datidens forhold hyppige sørejser have indvirket på denne billedbrug. Vi møder den i digtet "Historien" fra 1812 , trykt i Kvoedlinger fra 1815, hvor Noas ark og Pagtens ark i digtets sidste halvdel så at sige fusionerer, mens de omtumles på tidens bølger (US III, 94-97), og i den første titel: "Menneskens Liv", til digtet "Kirke-Skibet" (GSV VI/2, 216, sp.2).

Når Grundtvig inddrager havet direkte fra en bibelsk tekst, skærpes faren til en åbenlys trussel, der kun kan afværges ved guddommelig indgriben. Vi ser det i "Paa alle dine Veie" med citatet fra Es 17 og i det særdeles dramatiske søstykke, hvor Danmarks skæbne i 1864 indarbejdes i en oversættelse af Sl 104 (GSV V, 264). Denne bibelske billedbrug får et særligt præg, når han anvender den til at udtrykke den eksistentielle, varige trussel mod menneskelivet, døden var for ham. Det første tilløb hertil finder vi i "Som tørstige Hjort ..." i 1810-11 (GSV III, 35,4. DDS-2003, 410).

I det lys minder Grundtvigs brug af det truende hav i $\mathrm{B}$ så meget om Johs 6,16-21, at han kan ses som en i tid nok fjern, men i tankegang særdeles nær efterfølger for evangeliets fortæller, især hvis også denne har Karon i synsfeltet. Hos begge afviger fremstillingen af døden som aktivt ødelæggende magt fra den græske mytes billede af en uhyggelig grænse og afstand mellem livet her med dets handlemuligheder og døden selv som et dådløst efterliv. ${ }^{6}$

\subsection{Flere fælles motiver}

\section{Navigationsevnen}

Fartøjets evne til selv at finde vej er udførligt afmalet i A. Hvor det end sejler hen, har det den vind agterind, som bærer mod HimmelHavn (str. 5), og under havets overflade går der en stille strøm, som er med til at føre skibet af sted, men desuden skjuler Nådens Dyb sig under den, ikke graven (str. 6). Dertil kommer, at skibet "selv har Liv 
og Aand" (str. 10), og at "Han er Selv ombord, / Som skabde Hav og Snekke" (str. 12).

I B nævnes Guds Ord som retningsgiver (magnet/kompas) og Guds Ånd som rorgænger (str. 1 og 4 ).

Skibets besætning i C finder vej ud på Hjerte-Dybet, uden at det er nærmere angivet, hvordan der navigeres.

\section{Skibstyperne}

Skibstyperne er en næsten uoverskuelig sag. Vi hører en del om selve fartøjet i A. Dets konstruktion er i udgangspunktet blot "skrøbelig" (str. 1). Heller ikke efter fornyelsen til kirkeskib imponerer det: "Et Vrag dig Verden nævner" (str. 9). Alligevel har det plads til enhver, som har lyst til at sejle med det (str. 12). Uanset dets karakter af kirkeskib mindes man Frejs skib Skibladner, der ikke blot altid havde medbør, men kunne rumme alle Valhals guder, skønt det var bygget så spinkelt, at ejermanden kunne folde det sammen og tage det med, som var det et lommetørklæde.

I B er oplysningerne om skibet sparsomme. Det kaldes blot SjæleFærge (str. 3,5). Når man møder den glose i et digt om nært forestående død, tænker man uvilkårligt på den græske myte om Karon, hvis man da ellers kender den. Det gjorde dannede mennesker på Grundtvigs tid. I sin usle pram færger Karon de dødes sjæle til Hades, mens Sjæle-Færgen fører dem til Himmel-Havnen. Den modstilling er ligetil. Vanskeligere har jeg ved at se magnet/kompas (str. 1 og 4) som substitut for Karons stage (Lundgreen-Nielsen 1994, 116ø). Stagen kan ganske vist bruges til at korrigere kursen med, men den angiver ikke kursen, som kompasset gør det. ${ }^{7}$ Hos Grundtvig selv er der i øvrigt $\mathrm{i}$ anden sammenhæng en afvigelse fra traditionen om, at Karon bruger stage. I stedet ses han som rorkarlen, der haler $\mathrm{i}$ sine årer (Lundgreen-Nielsen 1994, 115n). Dertil kommer, at en pram er uanvendelig med de i A og B angivne farvandsudsigter og det uanset, om den bliver roet eller staget.

I C er skibet Simon Peters fiskerkvase (str. 1), der som redskab for det nye menneskefiskeri også kaldes snekke (str. 9), og brugerne udgør et færgelag. Der er funktionel lighed mellem Noas ark og Peters fiskerbåd. Den første bjerger levende væsener ( $G S V$ II, 8, 17), med den anden fanger færgelaget "Lyslevende Folk" (str. 6). 


\subsection{Fartøjer af forskellig art}

\section{Kirkeskibet og Frejs fartøj}

Selv om Grundtvig ofte taler om kirken som et hus, bør det ikke forbavse, at han også bruger billedet af et skib. "Hus" får os nok til først at se kirken som et bygningsværk, men billedet er ufuldkomment uden betydningen som i "Davids hus og slægt". For Grundtvig er kirken først og fremmest til som menighed, forsamlingen af mennesker, der bærer de kristelige livstegn: bekendelse, forkyndelse og lovsang. Derfor kan han påstå at:

Kirken er som Himmerige,

Meget kan den lignes ved ...

Mest dog lig en Barne-Moder,

Herren kalder den sin Brud,

Ved dens Mælk opvoxe Poder,

Som ved Bække Pile-Skud!

(GSV I, 19. DDS-2003, 327)

med henvisning til det genrejste Israel (Es 44,3-4) og måske hans elskede Davidssalmer (S1 1,3). Kendt er også "et aandeligt Rige" med "et præsteligt Folk", hvor 1 Pet 2,9 er på færde ( $G S V$ IV, 413. DDS2003, 318), og i GSV I, 58. DDS-2003, 409 er den via kirkeklokken nær ved at blive en høne med kyllinger (Matt 23,37). Også skibet har sine bibelske forbilleder, i NT Matt 8,23-27 par og Johs 6,16-21 par, i GT Noas ark (1 Mos 6,9-8,22), der i den kirkelige tradition via 1 Pet 3,20-21 og dåben kombineres med kirken. For Grundtvig kan derudover hans optagethed af Kingo have spillet en rolle. I et citat fra hans prædiken til 4. søndag efter helligtrekonger fra 1838 hedder det:

Saaledes sang jo ogsaa vor Kingo om Guds Kirke-Snekke, hvor Jesus lader som Han ofte hardt mon sove og saa for Vind og Vove sit Skib la'r tumle om ... (min markering af Kingo-citatet; tekst efter Schjørring 1990, 88-89).

Når hentydninger til Skidbladner tages i brug i digtet, har det antagelig sammenhæng med Grundtvigs vilje og evne til på overbevisende måde at inddrage også ikke-bibelsk materiale i sine salmer og andre kristne digte. I "Paaske-Liljen", hvis titel i sig selv er et eksempel på fremgangsmåden, indfører han i særtrykkene fra 1859 og 1863 Hading-sagnets hanegal som varsel om Opstandelsen ( $P S$ IV, $385 \mathrm{f}$. $D D S-2003,236,5)$. Kristi Genkomst bebudes ved, at luren gjalder (Heimdals Gjallarhorn?), og bavnen luer (GSV I, 400, 11. DDS-2003, 274). Brugen af Frejs fartøj i beskrivelsen af kirkens skib falder i tråd hermed. I den senere digtning bruges det samme fartøj et enkelt sted som lignelse for skjaldenes ord, der gennem sangen lader "Danne- 
Kvinder" have del i den evighed, som undervejs over tidernes hav ellers kun ses som genskær fra himlen (Toldberg 1950, 98-99; 252, note 24). Den funktion er ikke ganske ulig opgaven for skibet i A. Det er lokaliteten, hvor mennesket er inden for hørevidde af det ord, der "toner over Hav" og "under Sky" (str. 4 og 5). Det bæres af den understrøm, hvis "Gaade-Navn"'de Smaa" skal synge ud (str. 7). Og det er midlet til at "lande paa den Kyst, / Hvor Livet har sin Kilde" (str. 12).

I C. Prams epos Stoerkodder fra 1785, som Grundtvig med sit personlige kendskab til forfatteren vel har været mere end gennemsnitligt fortrolig med, gennemfører Skidbladner, som er udstyret med kompas (262), en farefuld færd med blandt andet en stranding i et bjerglandskab som Noas ark, dog med uheldige følger (267 ff.). Da sejladsen genoptages, anløbes stranden, hvor Mimer bor ved sin brønd, visdommens kilde ved livstræets rod (317). Her forenes Helga og Halvor i sand kærlighed, mens fornemmelsen af tidens forløb forsvinder for dem for en stund:

Thi Elskov, som grusomt belægger med Blye

De langsomme Timer, den Elskte henbringer

Adskilt fra sin Elskte, foreente paany,

Forsyner hver Time med Lynildens Vinger

(318)

Denne a-kronologiske tid (se afsnittet Dåben med note 15) og skibsfarten er fælleseuropæisk billedsprog (Hammerich 1933. Blumenberg 1979). I A bruges så et skib med spor af nordisk mytologi som udtryksmiddel for et element i Grundtvigs kristne livsanskuelse.

\section{Fajakerne og Noa}

Også andre kendte skibstyper end pramme giver besvær i B, str. 3 . Bedst ville den gamle færgesmakke fra 1800-tallets begyndelse passe, og det er den, også Fr. Paludan-Müller mindes i forbindelse med Karon (Lundgreen-Nielsen 1994, 114-15). Den var imidlertid udstyret med sejl og ror, og på grund af dens størrelse kunne hverken årer eller stage være mere end midlertidige hjælpemidler og det tilmed kun under land og i smult vande.

Den har i øvrigt haft Grundvigs sympati. Da han fortæller om, hvordan han efter 50 års forløb (ja!) igen passerer Storebælt forbi Sprogø, taler han om, at "Farvandet maa vel giælde for ligesaa nyt som Fargebaaden, der nu ligner langt mindre den gamle Børsmakke [sejlbåd, der kan udnytte medbør og bliden bør] end den æventyrlige Selv-Ganger, hvorpaa Phoakerne fordum bragte Odysseus til Thiaki" 
(US X, 68). De fajakiske fartøjers selvgangeri: at de navigerede efter mandskabets ønske uden styrmand og ror, er omtalt i Odysséens 8. sang, v. $555-63 .{ }^{8}$

I 13. sang, v. 73-124 findes beretningen om, hvordan Odysseus dybt sovende i skibets stævn (Sjæle-Færge-Stavnen?) sejles fra fajakernes land til Ithaka. Her hedder det yderligere om fartøjets særpræg:

Sikkert og støt gled skibet af sted så end ikke falken

kunne ha fulgt det, og den er den hurtigste fugl under solen ...

(v. 86-87. Otto Steen Dues overs. Gyldendal 2002)

Her er det mere farten end navigationsevnen, der imponerer, jf. "brat" i B, str. 3. Grundtvig har nok sejlet med skruedamperen "Kronprins Frederik Carl Christian", til daglig blot kaldet "Kronprinsen", der var indsat på ruten i 1844 (Mogens Nørgaard Olesen: Over Storebcelt $i$ 1000 år, Lamberth, 200, 16). Kølvandet efter et sådant skib kan vel have mindet passageren om følgende passus hos Homer:

og bag den [skibets agterstavn]

stod der en bovnende bølge af saltvandsskummende havvand (v. 84-85)

Søger man i det græske en pendant til et fartøj, hvis færd ender gunstigt, er dette skib en nærliggende mulighed, selv om dets passager i første omgang ikke kom hjem til fred, men til fejde. Færden ender i en havn, som er

en af de gamle $\mathrm{i}$ havet. Omkring den er tvillingepynter (...)

Inden for dem har velbetoftede skibe

end ikke brug for fortøjning, når først de er havnet herinde.

Ved havnen er der en grotte, helliget najaderne. Guder og mennesker har hver sin indgang til grotten:

To porte er der til grotten

én der vender mod nord og benyttes af menneskevæsner, én imod syd for de eviges æt ...

(uddrag af v. 96-112)

Også $\mathrm{B}$ har en tryg havn og gennem en port adgang til det evige. Under hjemlige himmelstrøg kan nævnes netop Nyborgs velbeskyttede havn, som Grundtvig anløb. I 1805 og 1855 har slottets anselige porttårn, hvorigennem kongens mænd i fordums tid gik ind til Danehof, præget byens silhuet ganske anderledes end nu. Med læ mod mange vinde og port til noget større en ikke uantagelig afglans af Sjæle-Færgens destination.

Selv om Grundtvig altså kendte til dampskibe, er der dog ingen grund 
til at forestille sig noget i retning af 1900-tallets jernbanefærger. Hans inspiration til brug af store skibe kommer andetsteds fra. Noa fik af Gud ordren: "byg en Snekke, / Og kald den Ark" ("Syndfloden", 1828, $G S V$ II, 8, 15). Fartøjets formål er oplyst med omhu i følgende strofe:

Naar Jorden hærges,

Fra Øst til Vest,

Med dig skal bjerges

Fuldmangen Giæst

Fra Bjerg og Dale

I Bølge-Sale,

Paa Havets Hest!

(str. 17)

og så møder vi den monstrøse linieskibsmodel:

De Kæmper trygge,

Med spodske Smiil,

Saae Noah bygge

Sin Ark med Iil,

Blandt Færreds-Snekker

En sær Tredækker

I Kæmpe-Stil!

Fuldbred som Hvalen,

Men længer dog,

(Trehundred Alen)

Det var den Kaag ...

(str. 18-19)

Vi ser en imponerende husbåd med umiskendeligt præg af at forudgribe kirkeskibet som menighedens hjemsted. Senere rummer beskrivelsen nemlig påfaldende mindelser om elementer i Grundtvigs billedsprog for den danske kirke og menighed. Nattergal og spurv, der omtales allerede i str. 21 sammen med svalen, giver i str. 38-40 lyd fra sig sammen med lærken som modvægt mod "vilden Strand" (str. 38) og "Bølgen blaa" (str. 40). ${ }^{9}$ Sangen fra fuglene i Noas ark er altså af en helt anden art end Uglesangen, selv om det oprørte hav udgør et fælles kontrapunkt, og den er derved med til at definere fartøjet som typologisk forbillede for kirken.

Den oprindelige syndflodsmytes tidsregning genoptages efter str. 42, som slutter:

For Væld franeden, For Bundløsheden,

Er Pind og sat! 
Her minder "Bundløsheden" stærkt om dødssymbolikken i "Bundløs der er Undergangen" i B, str. 3, som også af den grund synes at trække på hav- og urdybsmotivet i GT, måske især 1 Mos 7,11b: "netop på den dag brød kilderne fra det store urdyb igennem ...", jf. 1 Mos 8,2.

\section{Opsamling om skibet}

I 1870 kom digtene om Noas Ark og Færgelaget med i Sang-Vark til den Danske Kirke-Skole, og "Kirke-Skibet" blev aktualiseret ved Triers henvendelse. Derudover forekommer den med færgen sammenhængende ark så sent som i 1872, da Ernst Trier igen dukker op. Sammen med Grundtvig selv udvælger han af digtet "Kong Harald og Ansgar" fra 1000-årsfesten i 1826 nogle strofer, der under den typiske titel "Christi Kirke. (til Dana)" bruges i Sange for den kristelige folkeskole. Str. 1,1-4, lyder:

Dronning over Dane-Mark:

Sletten med de grønne Høie!

Ogsaa dig jeg bød min Ark,

Til den døde Sø at pløie!

(GSV III, 98, VI/2, 207. Hansen 1937, I, 114-15. 1966, III, 259)

Den alderstegne digter får således flere påmindelser om tidligere udformninger af det maritime motivmateriale, som tydeligt har trængt sig på, da $\mathrm{B}$ dannede sig $\mathrm{i}$ hans sind. Hvorvidt han på dette tidpunkt sent $\mathrm{i}$ sit liv også har haft fat i Karon-myten bortset fra i erindringen, tør jeg ikke udtale mig om. Den er utvivlsomt på færde, men som et tegn, der skal modsiges. Det fremgår, når vi ser hans andre sjælefærger, sådan som de nu lader sig rekonstruere. Der fremstår da et kompliceret billede.

Noas ark redder ham, hans nærmeste familie (de "otte Siæle") og alle dyrene. Den er forbillede for kirken som et skib med menigheden om bord. Selv bærer den reminiscenser fra linieskibene i slagene på Reden i 1801 og ved Sjællands Odde i 1808. Peters fiskerbåd klarer stormene på Genesaret sø. Hos Grundtvig fører den og dens Færgelag folk til Livets Kilde og til Gud, en tydelig beskrivelse af kirkens og menighedens funktion. Den kan være i familie med færgesmakkerne på Storebælt omkring år 1800 .

Den "Ark", som "Tømret er paa Ny", og som sammenlignes med "Snekken paa sin Færd", har spor af Frejs forunderlige fartøj. Antagelig er der også mindelser om fajakernes "Selv-Ganger", som førte Odysseus frelst hjem til Ithaka, og som Grundtvig i 1855 mindes ombord på en dengang nymodens dampfærge. Fartøjet i A er sammen med den ark, der tilbydes Dana "Til den døde Sø at pløie", ligeledes aftegninger af kirken og dens virke. 
Omsider dukker Karons pram op. Den kan nok ligne Præstø Fjords ikke-motoriserede åleruserøgteres små joller med deres lave fribord, men den er livsfjendsk. Færge, ark og snekke er til forskel herfra skibstyper, der er hjælpsomme mod døden i livets løb, ikke kun ved dets udløb. Et fartøj, der forener alle omtalte komponenter, lader sig ikke forestille, men da B bruger gode ord om færgefartens resultat, hælder jeg stærkt til Noas Ark som Sjæle-Færgens prototype. Den har potentiale både som præfiguration for Kirkens Skib og som kontrafaktur til Karons Pram.

Skønt glosen "Sjæle-Færge" uvilkårligt minder den orienterede læser om Karons dystre pram og dermed om dødens gru, må det fastholdes, at færgen hos Grundtvig henviser til de positive betydninger, denne ved sit slægtskab med andre fartøjer har hentet fra de bibelske fortællinger. Det må medhøres, at i alle disse positive betydninger indgår et moment af kirken som menighedens hjemsted. "Sjæle-Færge" lader sig på den baggrund læse og forstå uden vanskelighed også af mennesker, som ikke har kendskab til græsk mytologi.

Når baggrunden for betegnelsen Sjæle-Færge skal fastlægges, er det imidlertid i sidste ende ikke tekst-eksterne belæg for et litterært eller faktisk forekommende fartøjs art, størrelse og udstyr, der er det afgørende. Vi har først og sidst brug for at forstå fartøjets funktion og formål inden for digtets ramme og dermed $\mathrm{i}$ forhold til digterens/læserens eksistentielle vilkår: at mennesket som livsvæsen, "sjæl", bringes fra en kendt, faktisk tilværelsesform til et forkyndt eksistensvilkår, hvis art har aktualiseret sig ved erkendelsen af, at vore/digterens dage er ved at rinde ud. Formuleringen af denne situation hos Grundtvig og i den tradition, han er indlevet $\mathrm{i}$, har derfor krav på opmærksomhed.

\section{Gransesituationen i Antikken og hos Grundtvig}

I det følgende indplaceres Grundtvig $\mathrm{i}$ en gentagne gange opdukkende gren af den antikke tradition om døden. Det sker gennem udvalgte eksempler herpå, suppleret med et enkelt nutidigt udsagn inden for samme tradition, og markeringer af traditionen opsøges i A, B og C. Den anden gruppe fællesmotiver i de tre tekster: sang/forkyndelse, dåb og nadver, gennemgåes derefter for at fastlægge deres betydning for bestemmelsen af "Sjæle-Færge" som "Kirke-Skibet".

\subsection{Nogle gamle udsagn og et enkelt nyt}

Går vi til de oldtidsfolk, hvis skriftlige efterladenskaber har haft direkte betydning for vores kulturkreds, kan vi begynde hos grækerne 
med Homer. Han lader den døde Achilles beklage sig til den gamle kampfælle Odysseus ved dennes visit på Hades' strand på hjemvejen fra Troja:

Tal ikke til mig om trøst i min død, du gæve Odysseus!

Jeg ville hellere trælle for daglejerløn for en fattig fæster, der kun med nød havde nok til dagen og vejen, end være herre og drot blandt samtlige afdødes sjæle.

(Odysséen, 11. sang, v. 488-91. Otto Steen Dues overs., Gyldendal 2002)

Her er grænsesituationen åbenlyst en overgang til det værre, et synspunkt, der også lidt senere i tiden fremgår med al ønskelig tydelighed af ordsproget i den antikke jødedom: "Hellere levende hund end død løve" (Pr 9, 4b).

Efter endnu nogle hundrede år ser den romerske stoiker og kejser Marcus Aurelius mentalt mildere, men sagligt strengere på sagen: "Makedoneren Alexander og hans Æseldriver er begge døde og kommet samme steds hen: enten er de nemlig blevet optaget $\mathrm{i}$ Tilværelsens Grundspirer, eller de er blevet opløst i Atomer", selv om det sker med resignation:

Døden er en Udhvilen fra Sansernes Indtryk,

fra Lidenskabernes Marionetspil,

fra Tænkningens strenge Dagsmarcher,

fra hele dette vort Hoveri under Kødet.

(Begge citater: Selvbetragtninger, Hasselbalch, 1947, 32)

Her er formlen vel nærmest "Fra Livet til Ingenting". En sen og gribende frugt af denne tankegangs latente nihilisme møder vi i Poul Henningsens sidste digt, Mod nul:

Jeg har aldrig kunnet være alene

men elsket tosomheden.

Drømmen om samværet falmer.

Vist kommer du når jeg kalder

og formilder de næste sekunder.

Men bag dig ser jeg det store mørke:

Ingensomheden

(Hammerich 1986, 457)

Med sit "Vist (...) Men" er digteren på nippet til at eliminere den godhed, tosomheden efter hans eget udsagn har lagt ind i hans verden.

\subsection{Udtryk hos Grundtvig}

Hos Grundtvig møder vi gentagne gange udtryk, der viser, at hans holdning til dødens grænsesituation kan præges af antikkens syn på den som en grænse mod intet, men hos ham finder vi samtidig en til 
angst grænsende modvilje herimod. Tidligst er erindringsbilledet af det absolutte mørke over for den lysende kerte i studenterhybelen (US I, 63). Senere kommer det knudrede "fra det Bedre til det Værre" med "det Gode" som den fælles modsætning (GSV IV, 136, 8. Hansen 1951, II, 223-26). Fra samme periode (1843-45) er "Iistap-Haanden", der "Bortvifter Hjertets Varme" (GSV IV, 95, 9). I forhold til de klassiske forfattere, der er omtalt ovenfor, ligger billederne nok nærmest Marcus Aurelius, men deres underliggende angst forhindrer den resignation, som præger den stoiske kejser. I det stykke ligger de klart nærmere Poul Henningsens nutidige udtryk for følelsen af forladthed.

I B tager Grundtvig da også kategorisk afstand fra intetheden som det sidste ord i den sag, men han afviser den også i A og C. Det fremgår af, at sejladsen $\mathrm{i}$ dem ender med adgang til livet. I alle tre digte forankres muligheden for det modsatte af intethedens gru i henvisningen til de følger, Jesu færden har blandt mennesker, en henvisning, klassikerne - bortset fra Aurelius! - ikke har haft mulighed for, og som Poul Henningsen lader uomtalt. Hos Grundtvig medfører henvisningen, at grænseoverskridelsen skifter retning og kommer til at lyde: Fra Døden til Livet, og den isoleres ikke kun til at gælde ved afslutningen af vore dages tal, men dog også denne. ${ }^{10}$ Det fremgår af de fællesmotiver, der bærer dette tankekompleks i de tre sømandssange.

\subsection{Dødens røst i de tre tekster}

Det er vist velkendt, at Grundtvig kom til at se med dyb skepsis på den form for tankevirksomhed, der kan kaldes den spekulative fornuft, og som vil indordne alt under sine begreber, mens han respekterede "sensus communis", den sunde menneskeforstand, der klarer sig med, hvad man med rimelighed kan tilegne sig gennem erfaringen, navnlig den erfaring, historien kan stille til rådighed (se for eksempel US III, 401-17, artiklen "Om Videnskabeligheds Forhold til Erfaring og sund Menneske-Forstand” fra Danne-Virke II, 1817).

\section{Verdens Klogskab, Mandevid og Uglesang}

Den anden af disse måder at forholde sig til tilværelsen på, viser sig under de korresponderende udtryk Verdens Klogskab (A, str. 2) og Mandevid (B, str. 2). ${ }^{11}$ Denne form for fornuft er begge steder helt konsekvent anbragt mellem omtalen af farerne undervejs og beskrivelsen af, hvor galt det kan gå. I A står den mellem "Strøm og Storm og blinde Skiær" (str. 1) og "Tag vare dig for Dybet" (str. 2), i B mellem de utvetydigt truende "Stormene er frygtelige" (str. 2,1) og "Nærmest er de Dødes Rige" (str. 2,3). I A mener Verdens Klogskab 
at kunne give gode råd om, hvad der er at stille op: "Driv med Strømmen" (str. 2), men må lade sig sige: "Nei, I Folk paa Verdens Ø" (str. 3). I B, hvor udtrykkene er skærpet svarende til, hvad der gælder af formuleringen af faremotivet, afvises den mulighed blankt: "Stille staaer her Mandevid" (str. 2,2). Holdningen til fornuften er begge steder negativ i den forstand, at der ikke gribes om ondets rod: at livet antastes af døden. Verdens Klogskab i A negligerer forholdet, Mandevid i B er hjælpeløst. Motivet forekommer som undertone i afslutningen af $\mathrm{C}$ :

Hvo kun Alverden, ei Meer attraaer,

Han ei et Ord af vor Mund forstaaer,

Ham griber da ei vor Tale!

(str. 10)

dersom "Alverden" ses som det, "Verdens Klogskab" og "Mandevid" anser for acceptabelt.

Fornuften er særligt tydeligt med som en negativ faktor i B, hvis Uglesangen (str. 2,5) ud over nattemørket ikke begrænser sig til at signalere legemlig død i sin egenskab af at være "Djævelens fordærvelige uglesang" (Noack 1993, 108 med henvisning til Peder Tiedemans oversættelse af Luthers huspostil), men især skal minde os om Minerva, visdommens og tankens gudinde, der havde netop uglen som symbol. "I Minervas skikkelse har [Grundvig] samlet alt, hvad der er ham imod i tidens Aandsliv" (Toldberg 1950, 86n-87ø). ${ }^{12}$ Der føjes en særlig dimension til forståelsen af dødens karakter ved en sådan kobling til rationalismens syn på fornuften. Denne i Grundtvigs ungdomstid højest vurderede menneskelige evne, der også bevarer indflydelse, især i kirkelige kredse, langt ind i Romantikken, ses som redskab for dødens ødelæggende magt. Hvis Uglesangen har sammenhæng med Grundtvigs opfattelse af Karon som udtryk for "Reflexion eller Nakøie, fordi han seer tilbage, mens han roer frem" (LundgreenNielsen 1994, 115n), understreger det yderligere, hvorfor fornuften i rationalismens opfattelse af den for Grundtvig er livsfjendsk. Den vender jo ryggen til den fremtid, der også rummer døden, og kan derfor ikke sige noget i den sammenhæng.

Der findes dog hos Grundtvig en tredje vej til indsigt ud over den spekulative tankegangs i sidste ende destruktive virke og den sunde menneskeforstands pragmatiske tilgang til livet.

\subsection{Livets tale i de tre tekster}

I et udsnit af de sidste tre strofer fra digtet om Jesu læreår i Nazaret møder vi følgende udsagn:

Da har og Gud et Nazaret 
Til os ensteds paa Jorden ...

Der som Gud Faders egne Smaa

I Dagetal vi lære,

I Aandens Kraft at staae og gaae

Og tale til Guds Ære ...

Saa fyldes med den Viisdom vi,

Som Ydmyghed er Sjælen i,

Hvorved ei Hovmod hefter. ${ }^{13}$

Der sluttes med bønnen:

O, Gud skee Lov for Naadens Ord,

Til Trøst for dem, som græde!

Og Gud skee Lov for Jesu Spor,

Hvori de Smaa kan træde!

Og Gud skee Lov for Herrens Aand,

Som fører os i Ledebaand

Til evig Fred og Glæde!

(GSV IV, 247, 4-7. DDS-2003, 140)

Trods børnesangens meget enkle ordvalg er udsagnets karakter ikke uden styrke, bestemt af læringssituationen, som ikke er "den sorte skole" med grammatik og diskussionstræning om erkendelsens præmisser og grænser, ej heller "den folkelige højskole" med samtalen om menneskelivets daglige og eksistentielle vilkår. $\mathrm{Nu}$ er vi i menighedens forsamling, der lytter til og svarer på, lader sig inddrage i, Jesufortællingernes Kristusforkyndelse, der hos Grundtvig altid har et symbiotisk forhold til menighedens sang.

\section{Sangmotivet}

Dette motiv udfoldes bredt i A med hele tre dimensioner. I str. 4 gør "Fugle-Sang i Skoven" opmærksom på "den aabne Grav", der knyttes til de bevægelige elementer luft og vand (Skaberånden og Urdybet $\mathrm{i}$ Gen 1,2/Helligånden og dåbens vand i gudstjenesten?). Fugle-Sangen ses da bedst som emblem for forkyndelsen af Jesu opstandelse, som den genlyder i menigheden ned gennem tiderne, jf. "Som Nattergalens var hans Røst" om englens ord til kvinderne påskemorgen (GSV IV, 16, 3-5). Den åbne grav er derfor den grav, Jesus stod op af, og som også kan blive vores, jf. næstsidste strofe af "Min Jesus, lad mit Hjerte faae ...":

Mit Hjerte i den Grav, du laae,

Som opstod hvid og rød, Lad, naar det aftner, Hvile faae 
Og smile ad sin Død!

(GSV IV, 152,3. Hansen 1951, II, 250-51. DDS-2003, 217)

"Engle-Sang fra oven" kan også udtrykke Kristusforkyndelsen ved Jesu fødsel:

Og naar Herrens Fødsels-Glæde

Raabes ud med Engle-Røst,

Virkelig den er tilstæde,

Giennemstrømmer os med Lyst.

(GSVIV, 266, 6. DDS-2003, 320).

I A gør sangen også opmærksom på den nye ark, som kan gennemføre sejladsen til "Himmel-Havnen" (str. 5,3-6). Af str. 6 og 11 fremgår det, at denne nye ark er kirkeskibet. Og endelig bruges sangmotivet som en naturlig følge af forkyndelsen om menighedens takkesang "med Engle-Tunger" for den frelse, dåben bringer ved at aktualisere Jesu gerning (str. 7). Str. 10 hører måske også til i denne sammenhæng.

I B er motivet polariseret. Uglens antisang, groft sagt den autonome rationalitets begrebsverden, står over for "Guds Priis" hos "Ordet" (str. 3,4), dvs. menighedens takkesang for Gudsnærværet, som det er sat i værk ved Jesu liv, død og opstandelse. Der er tale om en koncentration af de tre dimensioner i sangmotivet fra A. Takkesangens henvisthed til forkyndelsen er ganske åbenlys, men Ordet er også Kristus-repræsentationen. Det svarer til den kombination af forkyndelse og tilbedelse, vi også møder i Mattæus-evangeliets gengivelse af Vandringen på Søen. Den slutter med, at "mændene i båden kastede sig ned for ham og sagde: "Sandelig, du er Guds søn"” (Matt 14,2223). Eneste forskel er, at den tilbedende gestus her går forud for den verbale formulering af, at begivenhedsforløbet ses som Gudsåbenbaring. Dette positive sangmotiv i B, str. 3, står som omdrejningspunkt $\mathrm{i}$ midten af både denne strofe og hele digtet og vinder derved betydelig vægt. På det andet sted i B, hvor sangmotivet forekommer (str. 5,2), bruges det om takkesangen for, at Gud er kommet os så nær, at han har omfavnet os med sin kærlighed, så "Hjertet er i Himmerig" (str. 5,4).

Sangmotivet viser sig ikke i C, men vi møder den offentlige forkyndelse i str. 9 og i den i $G S V$ VI/1, 156, sp. 1n, gengivne strofe, der var med i førstetrykket, jf. Malling I, 195-98:

I Mørket driver ei den sit Spil,

Som er i St. Peders Gilde,

Af ham kun fanges hvo gribes vil

Af sanddrue Ord og milde ... 


\section{Dåben}

Dåben er indirekte til stede i A, str. 5-7. I B findes den efter mit skøn som næsten selvindlysende baggrund i sammenstillingen af GudsOrdet med Guds Aand og Aanden i str. 1 og 4, jf. Konfirmationssangen til Meta i 1843:

Han døber med den Helligaand,

Paa Ord, som aldrig feiler

Han rækker os sin Haand!

(GSV III, 219,3. DDS-2003, 479,1)

Den grundtvigste dåbsaccent er yderligere åbenlys, hvis Evighedens Port, der i str. 4, 5-6 “åbner sig brat", er analog med det ni gange gentagne omkvæd i salmen om Jesu dåb: "Kom, følg i Aanden med / Til Jordens Færgested":

Her seer du over Daaben

Guds-Husets Dør staae aaben!

$(G S V \text { II, 66. DDS-2003, 142) })^{14}$

I $\mathrm{B}$, str. 4, understreges desuden på særlig måde den kombination af engangskarakter, uafhængighed af tidsregningen og åbenhed, som kendetegner dåben. Det sker dels med brugen af Evighedens Timeglas som tidsmåler, dels gennem selve opbygningen af strofen. I de andre strofer er midterlinjerne bærere af strofens hovedanliggende: afskeden (str. 1), faren (str. 2), løftet og dets modtagelse (str. 3) og nærheden (str. 5). I str. 4 er dette anliggende: dåben som Frelsens og Fornyelsens handling (Rom 6,4-5; 1 Pet 1,3-5), henlagt til de to indlednings- og de to slutlinjer. De to midterste linjer om den egenartede dimension $\mathrm{i}$ tidsbegrebet udgør derved et mellemrum, et åndehul, som føjer et særligt aspekt til dåbens engangskarakter, der i slutlinjerne understreges af "brat" og af, at disse linjer har mandlig udgang, mens de andre strofers slutlinjer har kvindelig udgang. Mellemrummet, åndehullet, medfører, at dåben ikke gøres til en privat binding, men til en personlig sag, der også er et fælles anliggende.

Ses der herfra tilbage på str. 1, falder formodningen om, at indledningslinjen: "Gammel nok jeg nu er blevet", er et citat fra sagnet om Norne-Gæsts besøg hos Olav Tryggvason (Lundgreen-Nielsen 1994, 119, note 1. US III, 176) næsten lige for, jf. også argumentationen for en art identifikation mellem Norne-Gæst og Grundtvig hos Toldberg $(1950,86 \varnothing)$. Afskeden i sagn og digt har dertil en vis strukturel lighed med hinanden. Norne-Gæst lader det lys tænde, der vil skille ham ved livet, når det brænder ud; digtets jeg har sat foden på falderebet til det fartøj, som fører ham væk fra "denne Verden". Norne-Gæst udfører sin handling med sindsro og modtager den sidste olie; digteren $\mathrm{i}$ 
"Bortgangskvæde" gør det med gru for døden, men i tillid til Kristi frelsende nærvær i den dåb, der allerede har ført ham "fra Døden til Livet", jf. henvisningen til Romerbrevet ovenfor i dette afsnit. Begge går ind til det uafvendelige med vidende og vilje. Kun i sindsstemning og holdepunkt over for det uundgåelige er der forskel. Sammenholdt med forekomsten af Ordet og Ånden i begyndelsesstrofens 1,5-6 betyder det, at denne strofe fastlægger digtets synsvinkel som den døbtes, selv om den henter sprog også fra den nordiske sagnverden.

Gudsnærværets mulighed, også i døden, har sammenhæng med den a-kronologiske, komplementært-flerdimensionale tidsforståelse, der finder sit udtryk i Evighedens Timeglas. Når dette timeglas "Giælder som i Eventyret", kan det være en hentydning til Tornerose, som var uberørt af tidens tand, selv om hun havde sovet $i$ hundrede år. Der kunne dog også være tænkt på eventyret om brudgommen, der fulgte en dejlig og smukt syngende fugl ind i skoven dagen før sit bryllup. Da han igen mødte landsbyens beboere, mente han kun at have været væk en times tid, men han opdagede, at der var gået flere hundrede år. Ingen genkendte ham nemlig, og kun nogle få af de ældste erindrede svagt et sagn fra gamle dage om en forsvunden brudgom. ${ }^{15}$

Grundtvigs brug af henvisning til eventyret som genre i stedet for til en bibelsk formulering kan hænge sammen med, at det kommer nærmere den alment-menneskelige forankring af strofens tidsforståelse. Den kendes fra barnets oplevelse af at blive kaldt ind til aftensmad, næsten før legen er begyndt, selv om der på uret er gået et par timer, siden det løb ud i haven. Vi møder den også i unge menneskers falden-i-staver, den voksnes opslugthed af dagens dont og alderdommens hvile i mindernes verden. Enkelte kender også til den mystiske oplevelses mentale suspension af bundetheden til den løbende tid.

Måske ligger der en tilsvarende tilskyndelse bag brugen af de fra de danske sunde, bælter og fjorde så velkendte færger ved beskrivelsen af grænsesituationen (str. 3) og af den i alle landsbyer, håndværkerlav og nabolag så fortrolige indbydelse til at markere hjemligheden, når Gud kommer på tale (str. 5,6).

I C hører vi om Livets Kilde som rejsens første mål (str. 7,4), hvorigennem mennesket når det endelige mål, som er Gud (str. 7,5). Formuleringen er nok bestemt af, at både inden for den tradition med barnedåb, Grundtvig levede i, og i den situation, som i aposteltiden, hvor evangeliet lyder for første gang, er dåben det første møde, mennesket som enkeltperson har med Gud. Det er også nødvendigt at medtænke Kristusskikkelsen fra dåben som Gudshusets dør for helt at gøre ret og skel over for udtrykket Livets Kilde, jf. GSV I, 46, der som 
gendigtning af Den apostolske Trosbekendelse, dåbsbekendelsen, er en væsentlig tekst:

Vi troe, som vi ved Daaben svor,

Paa Dig, Gud Fader, Livets Kilde...

Du Livet heller gav end tog,

Derfor Du til din Søn os drog...

Senere udfolder Grundtvig konstellationen Kristus/Kilden/Dåben langt mere udførligt. Vi finder den således i salmen "Helligaanden trindt paa Jord" fra 1858 med hentydning til Johs 1,1-5:

Livets Ord af Guddoms-Rod

Kilden er til Livets Flod,

Lysets Børn deri sig bade,

De af Daaben sjæleglade

Dukker op til evigt Liv!

(GSV V, 115. DDS-2003, 298)

og med inddragelsen af nadveren og inspirationen fra Johs 10,14-16 og S1 23,2 i "Hyrden er een, og saa hans Hjord" fra 1855:

Kilden er een og Floden med,

Er end Smaa-Bækkene mange,

Engene er ved Flodens Bredd,

Alle de skiønne Græsgange;

Kilde og Flod er Daabens Ord,

Engene er Vorherres Bord,

Føden er Kiærligheds Fylde!

(GSV IV, 334, 2. DDS-2003, 168)

En særpræget udnyttelse af kildemotivet som Kristusrepræsentation i udformningen af dåbens forhold til tidløshed og evighed forekommer i "Alle mine Kilder skal være i dig" (GSV V, 153. DDS-2003, 441). Efter at Kristi komme er blevet forankret i Israels historie (str. 1) og i inkarnationen (str. 2), omtales Jesu dåb (str. 3), vor dåb (str. 4) og lidelsens dåb (str. 5 Mark 10, 38-39), hvorefter pointen i str. 6 er, at hele skaberværket med Kristi gerning genfødes til fællesskab med den evige Gud. Str. 5-6 har således en vis strukturel lighed med Rom 6, 4-5 om fællesskabet med Kristus i "dåben til døden" og i livets fornyelse "ved en opstandelse, der ligner hans". Ud fra slutlinjen "Med alt, hvad Jeg evig bar hos mig" ser jeg i salmen også et mønster, der ligner 1 Kor 15,20-28. Her rykker på noget tilsvarende måde en tidslinje: Adam/Kristus som menneske/Kristi opstandelse, og en evighedsdimension: tilintetgørelse af "al magt og myndighed og kraft" ud fra Kristi herredømme og overgivelse af "Riget til Gud Fader", ind i 
samme perspektiv med konklusionen: "for at Gud kan være alt i alle". ${ }^{16}$

\section{Nadveren}

Nadveren nævnes i A, str. 11, under betegnelsen Brød og Bæger som skibets eneste proviant. Den er til gengæld uudtømmelig som olien og melet i huset hos enken i Sarepta (1 Kong 17).

I B er omtalen mere indirekte, men Guds-Bordet i str. 5, 6 om måltidet $\mathrm{i}$ himmeriget (Matt 8,11 par. Luk 13,29. Matt 22,1-14 par. Luk 14,15-24. Åb 19,1-10) står som digtets sidste udsagn med så betydelig vægt, at altergangen ved gudstjenesten får samme position som dåben. Det gælder også dens funktion som formidler af fælles identitet med Kristus. Udtrykket "vi indbydes" må jo være affødt af den konkrete formulering i nadverritualet: "Tag brødet og spis det". "Drik alle af vinen"."Gør det til min ihukommelse", det vil sige, så jeg indgår $i$ jeres erindring. Betegnelserne for brød og vin og handlingens effekt må også medhøres: "Dette er mit legeme" og “ (...) mit blod, som udgydes for jer til syndernes forladelse", det vil sige gives til jer til befrielse for alt, hvad der skiller jer fra hverandre og fra Gud. ${ }^{17}$ Sammen med altergangen må den gamle, endnu på Grundtvigs tid almindelige skik at modtage nadveren på dødslejet ses som det himmelske måltids foregribelse her i tiden. Så ligger afslutningen af menneskets åremål på jorden som et mørkt og stormfuldt hav mellem det jordiske og det himmelske måltid ved Guds-Bordet, på samme måde som den mørke og stormfulde Genesaret sø ligger mellem den praktiske mættelse på det øde sted, der får folk til at fremføre det fejlagtige ønske om at gøre Jesus til konge, og den eksistentielle gave i tegnet, som fremgår af talen i Kapernaum med Jesu ord om sig selv som Livets Brød (Johs 6,1-15, v. 22-59).

I C kan nadveren være baggrunden for talen i str. 7,5-7, om den frie færden ind og ud hos Gud i stadigt følgeskab med glæden, jf. altergang: at gå til stedet for Guds nærvær, brugt meget markant $\mathrm{i}$ kirkesalmen "Tør end Nogen ihukomme / Hjertets søde MorgenDrøm" (GSV I, 13. DDS-2003, 348). Her kaldes kirken "et GiæsteKammer / Til en himmelsk Alter-Gang" (str. 9). Desuden findes der tydelige paralleller til "Fiskervisens" glædesmotiv i to af Grundtvigs nadversalmer. Mest markant er det i "Mindes vi en fuldtro Ven" (GSV I, 372. DDS-2003, 445) med slutlinjen "Finde Glæden i din Favn!" (str. 4, 6), hvor glæden ikke er med i forlægget (Malling III, 333, sp. 1). I "Du er vor Skat, o Jesus sød!" (GSV III, 192. Uddrag i $D D S-200$, 467) møder vi "Fryd og Fred" som måltidets grundstemning (str. 1, 3), "Kom, følg med mig til evig Fryd" (str. 13,2), "Og ved mit Bord en 
evig Fest!" (str. 14,4) og "Og lad os i din klare Vin / Inddrikke Barneglæden din!” (str. 21,3-4). ${ }^{18}$

\section{Kirken som skib i de tre tekster}

Med forkyndelsens/sangens, dåbens og nadverens stærke placering i A og i $\mathrm{B}$, men også nødvendigt medtænkt i $\mathrm{C}$, må grundlaget for de tre digte være en kristendom i kirkeligt regi med hovedvægt på gudstjenesten. Blot må man erindre, at "kirke" hos Grundtvig er bestemt ud fra hans forståelse af Den apostolske Trosbekendelse. Han går ud fra forestillingen om et alle folkeslag omspændende fællesskab, en folkeforsamling, der ikke kaldes sammen ved kongens eller bystyrets befaling, men gennem evangeliets ord. I denne muld vokser så hos ham en række sproglige vækster, hvis rødder kan findes flere forskellige steder.

I "Kirke-Skibet" er det især den bibelsk-kirkelige tradition, der leverer materialet, men indlagt $i$ et alment fortællemotiv: den risikable sørejse, og med visse naturlyriske elementer: skov, blomstertæppe, fuglesang. I "Bortgangskvæde" finder vi en blanding af nordisk saga, græsk mytologi, folkeeventyr og maritim terminologi som bærer af grundsynet. "Fisker-Vise" holder sig til en enkelt beretning fra Lukasevangeliet med nærliggende inddragelse af udtryk fra det danske fjordfiskeris verden.

Båret af skibsbilledet er kirken som den menighed, der holder gudstjeneste med forkyndelse, dåb og nadver, således med i alle tre digte. Forenklet sagt fremhæver A kirke/menighed som historisk forekomst, mens B primært beskriver den som eksistentielt livsrum. C indtager et mellemstade, hvor den kristne eksistens i virksomhed til hverdag søger sit udtryk: "Færgelaget" har den fri, glædelige færden med Gud, der i 1 Mos 3,8a antydes som det oprindelige gudsforhold, som sit mål.

Skiftet i synsvinkel fra digt til digt er en naturlig følge af digterens ændrede situation. Fra 1830'ernes midte ser det omsider ud til, at andre vil værdsætte, hvad han anser for en væsentlig del af sit livsværk: fornyelsen af den danske menighedssang. I 1872 er livsværket fort til ende, så vidt det står til ham, og nært forude venter afslutningen på hans mange dages tal.

Denne situation forklarer intensiveringen af udtrykkene i B over for A og C. Nok sætter søfareren stadig sin lid til den samme bærekraft, som indtil nu har bragt ham gennem tilværelsen, men fremtiden er blevet væsentligt forkortet, og de forestående farer er blevet reduceret til én: døden, "den sidste fjende" (1 Kor 15,26). Sørejsen har dermed ændret karakter på så afgørende vis, at den må betragtes som 
en ny sejlads. Søfareren stiger så at sige om bord på ny. Nu gælder det den sidste færd. Dens forløb beskrives som mindre mageligt, end da Odysseus tilbagelagde den sidste etape af sine rejser: fra Fajakernes land til Ithaka, sovende trygt i skibets stævn. Dens udsigt er til gengæld mere fredfyldt.

\section{Svaret i "Bortgangskvade"}

Gennem et markant prædikencitat og et referat af en typisk salme belyses begreber og dynamik i det sprogunivers, hvormed Grundtvig udtrykker sin kristendomsforståelse, hans syn på Verden skitseres og arten af brugen af ikke-bibelsk materiale $i$ hans kristne udsagn beskrives. Derpå sammenlignes begrebsmønsteret i prædikencitatet med opbygningen af B, str. 3-5, der af digteren er sat over for den menneskelige situation, som opridses i str. 1-2. Sluttelig søges udsagnskraften i dette "svar til Karon" begrundet.

\subsection{Den kirkelige anskuelse}

De fælles motiver i A, B og C hænger klart sammen med Grundtvigs forståelse af, at kristendommen træder frem i et fællesskab, der er samlet om evangeliets forkyndelse, dåben og nadveren. Ud fra hans trang til at færdes i sproglige triader er det ikke mærkeligt, at disse tre elementer får hver sin af de sidste strofer i $\mathrm{B}$, så meget mindre som han, da han nærmer sig de 80 , i en eksemplarisk formulering af denne såkaldt kirkelige anskuelse udnævner dem til "de tre store Højtider" ("de tre smaa" er jul, påske og pinse, $H b G S$ III, 171):

$\mathrm{Ja}$, mine Venner, Evangeliets Forkyndelse med Daaben og Nadveren, det er ikke blot levende Minder om Frelserens, Vorherres Jesu Kristi Fødsel og Opstandelse og om hans Aands Udgydelse over Apostlene, levende Minder, som avle Haab om Delagtighed i Guds Frelsning; men det er guddommelige Vidnesbyrd og Saligheds-Midler fra Sloegt til Slagt, som meddeler alle sandhedskjærlige Hjerter den kristne Tro, det kristelige Haab og den kristne Kjærlighed, med Retfærdighed, Freden og Glæden i den Helligaand, som er de kristnes Himmerig paa Jorden (HbGS III, 171. Citat fra Sidste Prodikener I, 182-83, prædiken til pinsedag 1862. Mine fremhævelser).

Det er denne anskuelses særpræg, at dens begrebsdannelser ikke udgør et æskesystem, der lukker sig om sig selv, men danner en gruppering af kraftfelter med et personligt præg. Det sidste fremgår af betegnelserne "guddommelig", "kristne" og "i Helligånden" samt gennem henvendelsen til "alle sandhedskjærlige Hjerter". Åbenheden og dynamikken i tænkemåden, dens koreografiske træk kunne man sige, viser sig for eksempel i den måde, hvorpå treleds-grupperne: 
forkyndelse/tro/retfærdighed; dåb/håb/fred; nadver/kærlighed/glæde, kombineres med Himmeriget, Guds Rige, som det på karakteristisk vis fremgår af salmen: "Midt iblandt os er Guds Rige" (GSV IV, 266. $D D S-2003,320$ ). Her begyndes bagfra med "Hans Naadebord", kærlighedens måltid (str. 1), hvorefter dåben, at "os med Herrens Stemme / Aanden kalder hver isar", og håbet, "At Guds Rige kom os nær", nævnes (str. 3, min fremhævelse). Str. 4 taler om troen, der modtager "Ord og Aand i Jesu Navn" (Grundtvigs kursivering), en klar henvisning til forkyndelsen, så vi på forhånd smager "Rigets Frugt". Den hedder i str. 5-6 "Guds Retfærdighed" $(5,1)$, "Guds Fred" $(5,4)$ og "Herrens Fødsels-Glæde" $(6,1)$, så vi kommer tilbage til udgangspunktet i den tredje triade. Glæden foranlediges af den "EngleRøst" (6,2), der bringer budskabet om frelsen og ligger bag stroferne om "Rigets Frugt" og troen. Som afrunding fremhæves "Tro og Haab og Kiærlighed" (1 Kor 13,13) som "den gode Jord" (Matt 13,8), der beredes "Til en himmelsk Frugtbarhed" (str. 8). ${ }^{19}$

\subsection{Livet i Verden}

\section{Ude er godt ...}

Som påvist ovenfor bruger Grundtvig havet som billede på tilværelsens omskiftelighed og, når havet er hentet direkte i Bibelen, også på den eksistentielle trussel, døden var for ham. Heroverfor sætter han nu de verbale henvisninger til "de tre store Højtider" som associationskanaler til den livgivende Kristusforkyndelse i Jesus-overleveringens virkelighed og virkning i nutiden. Derudover anvender han en art suspension af tid og rum som nysgerrighedsprovokatør over for menneskeeksistensens rum- og tidsrelation, så man spørger: Hvad er det her for noget? Det sker i str. 3 og 4 med talen om, at Paradis på én gang er "langt af Led" og "Nært dog allevegne", og med udtrykket "Evighedens Timeglas". Den måde at sige tingene på giver også "evindelig" og "Himmerig" i str. 5 et skær af anderledeshed i forhold til tidens gang og fastlæggelsen af et bestemt sted.

Suspensionen sker ikke som en afvisning af den tilværelse, der leves i tid og rum. Der er tale om udtryk, som åbner tilværelsen, når den fryser til, og sætter et orienteringspunkt, når den opløser sig i kaos. På den baggrund kan bruddet med "denne Verden" i str. 5 ikke forstås som et tilbagefald til den foragt for jorden som levested, der af nogle betegnes med det noget unuancerede udtryk bodskristendom, og som kendes fra såvel 13-1400 tallet som 16-1700 tallet. Der er antagelig rødder tilbage til det skift fra agtelse for asketisk livsførelse til åbenlys verdensforagt, som indtræder "i samme øjeblik som Martyrkirken 
bliver Verdenskirke", det vil sige cirka år 325-50 (Holmquist og Nørregaard 1946, 184).

Hos Grundtvig er der tale om en afvisning af at bruge det praktiske, rationelt gennemskuelige, det tidsbegrænsede, betingede, "det timelige", som sit essentielle eksistensgrundlag og en opfordring til at basere sin tilværelse på indbydelsen til Guds-Bordet som indbegrebet af noget meget mere omfattende, noget åbent, nyt, "evigt". Der kan her henvises til benævnelsen af det i tid og rum kendte og beskrivelige liv som "det Bedre", døden som "det Værre" og det primære livsgrundlag som "det Gode" i salmen "Har vi toppet, maae vi dale" (GSV IV, 136,8. DDS 539, 2. Salmen er ikke med i DDS-2003).

En anderledes udformning af denne skelnen mellem Verden som et uholdbart livsgrundlag og som et i tid og rum indlejret, men gudsskabt, realistisk levested, møder vi i "Jeg kiender et Land" (GSV III, 86. $D D S-2003,651)$ og i "Verden, o Verden! Hvi frister du mig" (GSV IV, 159 , jf. $D D S-2003,623)$, hvor realismen i den sidste træder frem med de følgende fire ord: "Endnu under Hårene hvide", der minder om "Gammel nok jeg nu er blevet". Her har DDS-2003 ikke medtaget GSV IV, 159,5-6, hvorved Verden er gjort gudsforladt, hvad Grundtvig ikke havde tænkt sig. På en måde, der lader de udeladte strofer virke som parallel til slutlinjerne i "Jeg kiender et Land": "Mit Land, siger Livet, er Himmel og Jord, / Hvor Kiærlighed boer!", gøres livet og freden nemlig i disse strofer til Frelserens følgesvende ind i verden og igennem verden og til digterens/læserens ledsagere ud af verden " $\mathrm{i}$ Frelserens Fjed”. Nærværet som følgeskab har en parallel i, at livet i B str. 5,1-2, ytrer sig i salmesangen til Frelserens ære, og i, at freden i str. 5,6, indgår $\mathrm{i}$ indbydelsen til Guds-Bordet som glædens hjemsted, jf. "Finde Glæden i din Favn!" (GSV I, 372, 4).

\section{... hjemme er bedst}

Talen om indbydelsen er sammen med det afgørende billedudsagn:

Af Hans Kjærlighed omfavnet,

Hjertet er i Himmerig,...

(str. 5,3-4)

med til at tilføre "Bortgangskvædes" slutstrofe et anstrøg af hjemlighed, som giver den en bekendthedskarakter, der vel ikke er så påfaldende som den, det stormfulde hav fremkalder, men som ved sin mere stilfærdige tone fylder billedet med et på én gang udtryksfuldt og usentimentalt præg, der ikke kræver særlige litterære, men alene alment menneskelige og jævnt evangeliske forudsætninger. Menneskelige: venskab, familie, hverdag, fest. Evangeliske: Hvem Jesus er, 
og at virkeligheden bag dæknavnene Guds-Bordet, Himmerig, Paradis og Evigheden hviler på hans skæbne.

Ved at kærligheden har det sidste ord i digtet, fremhæves den helt specifikke placering, talen herom har i den kristne traditions ytringer om Gud. Umisforståeligt er i 1 Johs 4, 16b: "Gud er kærlighed, og den, som bliver i kærligheden, bliver i Gud, og Gud bliver i ham", men vi møder dette særpræg allerede i 1 Kor 13,13 om fuldkommenhedens karakteristikum: "Så bliver da tro, håb og kærlighed disse tre. Men størst af dem er kærligheden", i dansk salmetradition kendt fra Brorson:

Naar troe og haab er omme,

At vi til himlen komme,

Skal kierligheden brænde

Først ret og uden ende.

(Brorson 1953, 147. DDS-2003, 690),

der videreføres af Grundtvig, som taler om

Kiærlighedens guldprude Stad,

Hvor Gud er Lyset saavelsom Livet,

Hvor Troen smiler,

Hvor Haabet hviler,

Hvor evig iler

Kun Gudskeelov!

(GSV V, 165, 3. DDS-200, 383)

Her kan man selv uden digterens understregninger se, at glædesmotivet, der afslutter strofen, er substitut for nadverens korrelat: kærligheden, mens dette motiv i B, str. 5,1-2, er henvisning til nadveren selv, som for eksempel også i; "Istemmer over Herrens Bord / Nu Kiærlighedens (1853: Menighedens) fulde Chor!” (GSV III, 266, 5. VI/3, 267-8. DDS-2003, 290).

Som B, str. 5, gennem kærligheden henviser til nadveren, den tredje "store Højtid" i pinseprædikenen fra 1862, er der i str. 4 sammenhæng til det håb, som knytter sig til den anden højtid, dåben, mens str. 3 knapt så umiddelbart, men alligevel markant gengiver et særpræg ved forkyndelsen, den første højtid; det fremgår af, at Ordet $($ str. 3,4) bliver besvaret af Guds Priis (ibid.), der er troens kendetegn hos dem, der med "sandhedskjærlige Hjerter" tager imod Ordet.

Stroferne 3-5 lader sig også jævnføre med de tre udtryk for "de kristnes Himmerig paa Jord" fra pinseprædikenen. Retfærdigheden set med Guds øjne kan iagttages ved, at "Sjæle-Færgen" (str. 3,5) sejler ind i "Himmel-Havnen" og ikke ender på havets bund eller Hades' strand, jf. freden som den gådefulde følge af Guds retfærdighed i "Midt iblandt os er Guds Rige", str. 5 (GSV IV, 266. DDS-2003, 320). 
Denne fred er hos Grundtvig nøje knyttet til netop den dåbshandling, der er baggrund for str. 4 (Thodberg 1989, 104-117). Det tredje element i "de kristnes Himmerig paa Jord", glæden, er åbenlyst til stede i B, str. 5 , i takken til Gud. ${ }^{20}$

I Bortgangskvæde former "de tre store Højtider" således digterens svar til Mandevid og Uglesang og, da Karon jo er medtænkt, også til ham og hans bedrøvelige virke. Kendskab til et nordisk sagn, en græsk myte og et bestemt folkeeventyr er ikke nødvendigt for at forstå digtets første linje, sjælefærgen og åndehullet i str. 4, men det uddyber udtrykkenes udsagnskraft betragteligt, også som baggrund for digtets positive udsagn i grænsesituationen. Man kunne vel sige, at Grundtvig bruger profanlitterære formuleringer som brændeknuder på det bål, hans insisteren på en kristen livstydning har tændt $\mathrm{i}$ hans sproglige univers. På lignende vis intensiveres styrken i digtets kristne forkyndelse, når man gennem "de tre store Højtider" erindres om fortællingerne bag gudstjenestens centrale fænomener og gør sig bevidst om Grundtvigs egen anskuelse om deres virkelighed og virkning i menneskers og menighedens nutidige liv.

\subsection{Digtets og svarets opbygning}

Når den kirkelige anskuelse udtrykt gennem bestemmelsen af forkyndelse, dåb og nadver som "de tre store Højtider" danner baggrund for str. 3-5, kan opbygningen af digtet og af dets svar på grænsesituationen opstilles således:

I

Situationen

a) Konstatering: Du er gammel

str. 1,

b) Konklusion: Døden er skræmmende adskillelse

c) Lyspunkt: Selv da gælder Guds kærlighed

II

Udfoldelse af konklusionen

a) Menneskelig indsigt slår ikke til over for døden

str. 2,

b) Det er nemmest at lade død være død

III Lyspunktets kendetegn

a) Forkyndelsens tilsagn om, at Paradis er nær

b) Dåben som døren til Evigheden

str. 3

c) Nadveren som forudgriben af gudsnærværet i Himmerig

str. 4

str. 5 
Strukturen i str. 1 ligner en sammenpresset gentagelse af de tre første strofer fra "Gud Herren saae til Jorden ned" (GSV IV, 78. DDS-2003, 493). Første strofe i denne salme rummer Guds klare og kontante konstatering af menneskeverdenens elendige forfatning: "Men trindt paa Jord ei fandtes Een / For Gud uskyldig, hjertereen (...)", svarende til digterens konstatering af egen alderdom i B, str. 1,1-2. Af anden strofes "Men ak, jeg veed ei heller Tal / Paa mine Feil og mine Fald" fremgår det, at digteren drager en lige så skånselsløs konsekvens som $\mathrm{i}$ $\mathrm{B}$, str. 1,3-4. Tredje led i begge tekster, henholdsvis str. 3 og B, str. 1,5-6, indeholder en udefra kommende løsningsmulighed $\mathrm{i}$ den fastlåste og håbløse situation, henholdsvis troen på Guds Søn:

Den Rene Jeg [Gud] har fundet,

Det er min Søn, men dog en Mand,

Og blive skal for Mig som han

Enhver som troer paa Sønnen!

og mulighedsbetingelsen for denne tro:

Magneten er Guds-Ordet

Og Guds Aand staaer selv ved Roret.

Forskellen ligger mere $\mathrm{i}$ formuleringen end i meddelelsens følger. Guds-Ordet har hos Grundtvig altid affinitet til Guds Søn gennem 1 Johs 1-14, og i "Gud Herren saae til Jorden ned", str. 6-7, ses det i B, str. 1,5-6, stramt gengivne samspil bredere udfoldet.

I str. 2 møder vi et sprog, der er indholdsmæssigt enkelt og formelt ganske ligefremt. Sammen med den bestemte form "det store, vilde Hav" peger det på, at der ikke gives udtryk for en ny og overraskende erkendelse. Digteren, og dermed læseren, konfronterer sig med en gammel, velkendt trussel, som nu viser sit sande ansigt. Mandevid og Uglesang udsiger begge afmagt over for situationen. 2,4 er mere generelt i sin form end 2,6. Derfor mener jeg, at "dér" i 2,6, som peger tilbage mod "de Dødes Rige" i 2,3, er set fra Uglesangens synspunkt. Jeg aner et uskrevet kolon efter 2,5 og tilsvarende anførselstegn om 2,6. Tegnsætningen i manuskriptet er ikke overvældende udførlig eller konsekvent, så vidt jeg kan se på fotokopien i $G S V$ IV/3, 524-25. Der er også mere karakter af direkte tale i 2,6 end i 2,2 og 2,4. Uglesangen, den spekulative fornuft med dens påstand om "Undergang", intethed efter døden, er dermed også mere personligt anfægtende for Grundtvig i forhold til livets afslutning end "Mandevid" med den praktiske forståelses enkle uformuenhed, at vi kommer "de Dødes Rige" nærmere i livets løb, "Nemt er det at stævne did" $(2,4)$. 
Undergangen ser altså ud til at være Uglesangens påstand. Den er nærliggende, men for digteren uantagelig og begrænset derved, at den regner "paa jordisk Viis" (str. 3,1). Derfor kan digteren ikke uden sværdslag lade den afgøre sagens endelige udfald. Det viser modstanden i de insisterende adverbier "Vel", "Ja" og "Derfor", som indleder str. 3, 4 og 5, der også af den grund må læses som en sammenhæng. De støttes af det indlagte "dog” i str. 3.

Går vi da til str. 3, hævdes det, at der findes et oprindeligt, meningsfyldt mål i, med og for menneskelivet; det kaldes Paradis. Hvor forkyndelsen, det vil sige budskabet om Jesus Kristus, lyder, værdsættes og accepteres $(3,4)$, er grænsesituationens bortvendte side ikke intethedens tomhed og gru, de gamles horror vacui, ej heller et dødsrige, hvis afgrænsning over for os er den tågede flodbred, der modtager Karons pram. For de ombordværende på Sjæle-Færgen er afgrænsningen en åbning mod Tilværelsens Grund for nu at tale Tillich'sk. Den er Himmel-Havnen, Noas Ark på Ararats Bjerge (1 Mos 8, 1-5). Et tilsagn om tryghed.

Helt fremmede over for Tilværelsens Grund er vi ikke. Str. 4 tilsiger os muligheden for meddelagtighed i menneskelivets oprindelige og endelige mål allerede nu. Forud for, at færgen fortøjes $\mathrm{i}$ havnen, inddrages vi i det fællesskab, der er meningsbestemt ved, at det lader sig lede af Aanden og har rejsemål fælles med og er fastholdt af Ordet, det vil sige Kristus (1 Johs 1, 14). Målet hedder Evighedens Port, den åbenhed, der står som regnbuen over sletten ved Ararat (1 Mos 9, 12-17), og som træder frem i fortællingerne om Jesu dåb (Matt 3,13-17 par). Den åbenhed fastholdes for os ved, at dåbsfællesskabet med Kristus danner et livsløb på fornyede vilkår, selv om det går gennem døden (Rom 6, 3-5. 1 Pet 3, 18-22). ${ }^{21}$

I str. 5 ser digteren det som en selvfølge, at ophavsmanden til omkalfatringen af grænsesituationens konsekvens fra undergang til åbenhed gøres til genstand for ubegrænset taknemmelighed ved, at han til stadighed og åbenlyst nævnes ved navn for dette godes skyld. Åbenheden ses i sammenhæng med inddragelsen i hans kærlighed; derfor kan digteren frigøre sig fra "denne Verden", tilværelsen for så vidt vi kan erkende den rationelt og håndtere den praktisk, men som den også destrueres af Uglesangen. Der lyder nemlig et mod-ord til Uglesangen: indbydelsen til Guds-Bordet, og det lyder allerede forud for, at vi lægges i graven.

Udover at være led i str. 3-5 som imødegåelse af det generelle trusselsbillede i str. 2 danner str. 5 også led for led modbilleder over for udsagnene i denne strofe. Tavsheden i 2,1-2, udskiftes i 5,1-2, med sangglæden, svarende til komplekset forkyndelse/takkesang. Dødsriget, man i 2,3-4 nemt kan nå selv, erstattes i 5,3-4 med hjertets 
tilstedeværelse i Himmerig, fordi en andens kærlighed omfavner det; det bringer "favn"-konnotationerne i Grundtvigs dåbssyn i erindring (Thodberg 1989, 36-51). I stedet for den undergang, der i 2,5-6, forudsiges af ord, som er i stand til at lægge verden øde, stilles i 5,5-6, indbydelsen til Guds-Bordet, nadveren, der giver liv, glæde og næring til deltagerne.

\subsection{Konklusion}

De poetisk-bibelske elementer i "Bortgangkvæde", str. 3-5: Paradis, Evighed, Himmerig, Guds-Bordet, optager gennem "de tre store Højtider" resonans fra hele den kristne tradition tilbage til NT og dettes forudsætninger i GT. I kombination med den stramme sproglige økonomi i stroferne forlener det denne brug af den kirkelige anskuelse som mulig livsholdning i grænsesituationen med en egenartet udsagnskraft. Den viser sig ikke kun, når menneskelivets slutfase tårner sig op i billedet af det stormpiskede hav, men også når dens præg af øde og tomhed trænger sig på $\mathrm{i}$ andre former, der kan hentes udtryk for $\mathrm{i}$ antikkens litteratur eller næsten billedløst i nutidens nihilisme. Vi møder en fri, men indlevet anvendelse af forskellige traditioner og brug af et både konsekvent og spændstigt billedsprog, der omformer den personlige, næsten private indsigt hos Grundtvig, så hans gennemtænkte og dynamiske anskuelse af kristendommen lader sig opfatte som et udsagn af almen art om et fælles fænomen i mennesketilværelsen.

Naturligvis har heller ikke han et erfaringsbestemt grundlag for at tale om det fremtidsvilkår, vi kalder at være død. Hans tydning af tilværelsen $\mathrm{i}$ forhold til grænsesituationen trænger sig dog så langt frem mod sprogets grænse, at tilværelsen for ham stadig forbliver "i live" helt ud i dens yderste for os erkendbare kroge, også selv om han er "gammel nok". Hans brug af Jesus-traditionens og kristentroens livsbårne og livsbærende ledemotiver til denne tydning inddrager deres insisteren på, at der er en bag fænomenerne uset forekommende, men af menneskelig tale dog formulerbar, uopslidelig syntese af det åbne og det fælles. Over for døden virker denne syntese på to måder. Den aflaster de efterlevende for den ligegyldighedsvægt, nihilismen og resignationen bebyrder menneskers kærlighed med ved at reducere eller eliminere dens værdi, netop når den er mest betydningsfuld. Syntesen befrier også for den overanstrengelse af menneskets kærlighedsevne, det er at lade livets fylde bero alene på den. Det træder hos Grundtvig frem i strofen:

See, jeg døer, men Gud med eder

Evig lever i sit Ord, 
Der Ham finder hver, som leder,

Der Ham favner hver, som troer,

Føler, selv i Død og Pine,

Han til Enden elsker Sine!

$(G S V \mathrm{~V}, 164,8)$

hvor ordvalget "Han (...) elsker Sine" er ensbetydende med det traditionelle Guds Kærlighed om syntesen af åbenhed og fællesskab. ${ }^{22}$

I "Bortgangskvæde" tilbyder Grundtvig ord for denne overbevisning om en større styrke bag kærligheden end den, vore egne kærlighedsevner kan mobilisere. Han gør det til enhver, som med poetisk, praktisk og realistisk sans lægger øren til og derudfra lader tydningens gyldighed komme an på en prøve i egen tilværelse. Dette krav om at sætte sig selv ind i tydningen er også nærværende $i$ andre tekster fra hans hånd. Måske i dem alle. I den forstand er de eksistentielle på næsten kierkegaardsk vis. Svaret på tydningens gyldighed gives hverken på forhånd eller på anden hånd. ${ }^{23}$

\section{Kildetekster, noter og litteratur}

\section{Kildetekster}

\section{A: Kirke-Skibet}

1. Livet her ret lignes ved

Et Skib paa Verdens-Havet,

Bølge op og Bølge ned,

I Dybet let begravet,

Udsat, som Snekken paa sin Færd,

For Strøm og Storm og blinde Skiær

Og skrøbelig kun lavet!

2. Verdens Klogskab raaber ud:

"Tag vare dig for Dybet,

Driv med Strømmen, gaa dit Skud,

Og lær din Kunst af Krybet;

Ja see dit Snit og pas dit Roer,

Læg alle Aarer brat ombord,

Naar Leiligheden vinker”!

3. Nei, I Folk paa Verdens $\varnothing$,

De Kloge med de Dumme,

Seiles maa den høie Sø,

Hvor ranke Bølger skumme,

Skal Farten lykkes over Strand,

Skal vi ved Livets faste Land

Engang vort Anker kaste. 
4. Hør, det toner over Hav Som Fugle-Sang i Skoven: "Bedre er den aabne Grav I Skyen og i Voven;

End Ulve-Graven svigefuld, Hvor Blomster gjøgle over Muld Og Orme-Flokken lurer!"

5. Hør, det toner under Sky som Engle-Sang fra Oven: "Tømret er en Ark paa Ny, og den kan trodse Voven, Ja, hvor den gaaer i Jesu Navn, Den følger Bør til Himmel-Havn, Og aldrig den forældes!"

6. Af et lønligt Kildevæld, Som Jordans klare Bølger, Sprang en Strøm til Folke-Held, Som Arken stadig følger, Den skiærer Verdens vilde Hav, Og under den slet ingen Grav, Kun Naadens Dyb sig dølger!

7. Rednings-Strøm fra Øst til Vest, I Tiden og i Rummet, Lige klar i Blik og Blæst,

Og aldrig overskummet, Du stille Vei til Fredens Havn, Udsjunge skal dit Gaade-Navn De Smaa med Engle-Tunger!

8. Ark! Du est og underfuld, Du bygdes uden Hænder, Kosted ikke Sølv og Guld, Som Verdens Øie blænder, Men kosted Ham, som dig os gav, Dog meer end Himmel, Jord og Hav, Det Kjæreste han kiender!

9. Uden Mast og uden Speil, Et Vrag dig Verden nævner, Uden Anker, uden Seil Du over Hav dog stævner, Og vakler kun, naar Mand af Jord Vil raade med dit fine Roer, 
Til han gaaer over Borde!

10. Hvad den største Helte-Skjald Opdaged kun i Drømme, Helgen-Skaren uden Tal Lysvaagen skal berømme, Det Skib, som selv har Liv og Aand, Som trænger ei til Styrmands Haand Og leer ad Hvirvelvinde!

11. Al din Kost er kun et Brød $\mathrm{Og}$ al din Viin et Bæger, Hver en Gjæst i Hungersnød Dog føder du og qvæger, Som Melet fiint i Enkens Huus Og Olien i hendes Kruus Dit Forraad ei fortæres!

12. Komme hver da, som har Lyst, Skjøndt Verden spaaer os ilde, Til at lande paa den Kyst, Hvor Livet har sin Kilde, Og troe kun fast på Herrens Ord, Usynlig Han er Selv ombord, Som skabde Hav og Snekke. (GSV III, 124)

B: [Bortgangskvoede]

1. Gammel nok jeg nu er blevet Mellem Vugge min og Grav, $\mathrm{Nu}$ jeg staaer paa Falderebet Ved det store, vilde Hav, Hvor Magneten er Guds-Ordet og Guds Aand staaer selv ved Roret.

2. Stormene er frygtelige Stille staaer her Mandevid, Nærmest er de Dødes Rige Nemt det er at stævne did, Men o vee for Uglesangen Bundløs der er Undergangen.

3. Vel, paa jordisk Viis at regne Langt af Led er Paradis Er os nært dog allevegne Hvor hos Ordet er Guds Priis, Saa for Sjæle-Færge-Stavnen 
Brat sig aabner Himmel-Havnen!

4. Ja, hvor Aanden staaer for Styret, Og Guds-Ordet er Kompas, Giælder, som i Eventyret, Evighedens Time-Glas, Der sig brat, som sagt, saa gjort Aabner Evighedens Port.

5. Derfor Jesus-Christus-Navnet Prises skal evindelig, Af hans Kiærlighed omfavnet, Hjertet er i Himmerig, Naar med denne Verden brydes, Til Guds-Bordet vi indbydes! (GSV V, 350.)

\section{C: Aandelig Fiskervise}

1. Der sad en Fisker saa tankefuld,

(1) Og hørde paa Herrens Tale, Saa klang i Øret ei Sølv og Guld, Ei Sangen i Havfru-Sale, Paa Fisker-Kvasen vor Herre sad, Og Folk i Mængde som Blomst og Blad De lytted i Land til Ordet!

2. Nu, Simon! sagde Gudfaders Ord,

(2) Da Prædiken hans var ude, Læg alle Aarer nu flux om Bord, Dem lystrer jo vel din Skude, Far ud paa Dybet og drag en Dræt! Det er paa Tiden, om jeg seer ret, Mig lyster med dig følge!

3. Ja, Lære-Mester! han svared brat,

(3) Det kunde vi godt behøve, Vi sleed forgæves den hele Nat, Dit Ord er og værd en Prøve! For Tvivl var Simon slet ikke fri, Men, speil, du Tvivler, dig smukt deri! Han gjorde som Herren sagde.

4. Sin Dont han passed og Vodd han trak,

(4) Men fandt, det var over Magten, Hans Skude nikked og Voddet sprak, Saa overhaands stor var Dragten, 
Da vinked Simon ad Venner troe,

Og Fiske-Ladning fik Skuder to,

Saa færdig de var at synke.

5. Der Simon Fisker det Jærtegn saae,

(5) Da Jesus han faldt til Fode,

Og sagde: Herre, du fra mig gaae!

Jeg er ikke af de Gode,

$\mathrm{O}$, laae jeg rolig kun under Muld!

Gud bedre mig! jeg er syndefuld,

$\mathrm{Nu}$ falder det mig paa Hjerte!

6. Vor Herre saae til den Synder mildt,

(5) Og sagde: vær kun ei bange!

Jeg vil dig lære herefter snildt

Lyslevende Folk at fange.

Hvad vil du, Herre! Det er et Ord,

Saa raabde Simon og sprang fra Bord,

Fra Alt hvad end sit han kaldte!

7. Saa fulgde Simon Vorherres Kald,

(6) Hos Ordet gik han i Skole,

Og Folk han fanged i Tusindtal,

De skinne nu klart som Sole,

Og end er ikke paa Jord forbi

Det store Menneske-Fiskeri,

Som Herren og Simon grunded.

8. Paa Jord end findes det Færgelag,

(7) Som kaldes Sanct Peders Gilde,

Saa Folk vi fange endnu i Dag

Og føre til Livets Kilde,

Fra Verden fore vi dem til Gud,

Hvor frit de evig gaae ind og ud,

Og Glæden dem altid følger!

I Mørket driver ei den sit Spil, Som er i St. Peders Gilde,

Af ham kun fanges hvo gribes vil

Af sanddrue Ord og milde,

Ei Naaden bruges som Lokkemad,

Med Sandhed klarlig den følges ad,

For Herren er i dem Begge!

9. Med Lys vi komme, med Kors vi gaae,

(8) Vi vil ingen Sjæl bedrage,

De veed det Alle, vi kalde paa,

At Verden de maae forsage, 
Paa Snekken vaier det røde Flag, Vort Garn vi sætte ved høilys Dag, Og ei i de smalle Sunde.

10. Paa Hjerte-Dybet vi fare ud,

(9) Hvor Timeligt ei kan bunde, Der Vodd vi trække paa Herrens Bud For hvad ei vil gaae tilgrunde, Hvo kun Alverden, ei Meer attraaer, Han ei et Ord af vor Mund forstaaer, Ham griber da ei vor Tale!

Str. nr. u. parentes: GSV II, 74 (titel her: Simon Peders Kald)

Str. nr. i parentes: $D D S-2003,147$

Str. u. nr.: $G S V$ VI/1, 156, sp. 1n

Str. (5) består af str. 5,1-4, parafrase af str. 6,1-2: "Frygt ikke! sagde vor Herre mildt", samt str. 6, 3-4.

Forkortelser og litteratur

\section{Grundtvigtekster:}

GPV = Holm, J. et al. (2003), Grundtvig Pradikener $i$ Vartov 1839-42,

bind I-IV, København.

$P S=$ Grundtvig, Svend et al.(udg.) (1880-1930), N. F. S. Grundtvigs

Poetiske Skrifter, bind I-IX, København.

$U S=$ Begtrup, H. (1904-1909), Nik. Fred. Sev. Grundtvigs udvalgte

Skrifter, bind I-X, København.

GSV = Balslev, Th. et al. (1944-64), Grundtvigs Sang-Vark, bind I-

VI, København.

GrSt $=$ Grundtvig-Studier, København.

$H b G S=$ Borup, E. J. og Fr. Schrøder (1929-31), Haandbog i N. F. S.

Grundtvigs Skrifter, bind I-III, København.

Krønnike-Rim, udg. af Svend Grundtvig, 3. udgave (1875)

Aandeligt Siunge-Koors Anden Part, 1681. Samlede Skrifter III,

København (1975).

\section{Andre tekstsamlinger:}

Bibelen: Hvis ikke andet angives, bruges den autoriserede oversættelse

(AO) 1992 (fx Johs 1,14).

DDS-2003: Den Danske Salmebog, 2003.

DDS: Den danske Salmebog, 1953. 
Malling: Enkelte tekster og citater bringes efter eller henvises der til i Anders Malling: Dansk Salmehistorie, I-IV, 1962-66.

Pram, C. (1785), Stcerkodder: Et Digt i femten Sange, København. Walther, H. (udg.) (1963-69), Proverbia sententiaeque Latinitatis medii aevi = Lateinische Sprichwörter und Sentenzen des Mittelalters in alphabetischer Anordnung. Carmina medii aevi posterioris Latina; bd. II/3, Göttingen.

\section{Bøger og artikler:}

Aulén, G. (1946), Dogmhistoria. Den kristna lärobildningens utvecklingsgång från den efterapostoliska tiden till våra dagar, Stockholm.

Aurelius, M. (1947), Selvbetragtninger, Hasselbalch.

Blumenberg, H. (1979), Schiffbruch mit Zuschauer, Frankfurt am Main.

Bradley, S. A. J. (1993), “"The First New-European Literature' N. F. S. Grundtvig's Reception of Anglo-Saxon Literature" in A. M. Allchin et al. (eds), Heritage and Prophecy. Grundtvig and the English-Speaking World, Aarhus and Norwich, 45-72.

Brorson, H. A. (1953), Samlede Skrifter, bind. 2, v/L. J. Koch, København

Bultmann, R (1998), Das Evangelium des Johannes, Göttingen.

Bøye, M. (1998): "Hallen og Havet", Grundtvig-Studier 1996, bind 47, København, 120-41.

Clausen, P. Balslev (1991), Det vingede ord, København.

Dass, Petter (1980), Samlede Verker, I, Oslo.

Hammerich, L. L. (1933), Munken og Fuglen, København.

Hammerich, P. (1986), Lysmageren, København.

Hansen, U. (1937-66), Grundtvigs Salmedigtning, dens Historie og Indhold, bind I, Odense, bind II-III, København.

Holm, J. (1997), "Salmen At sige Verden ret Farvel - belyst ved

Grundtvigs samtidige prædikener", Grundtvig-Studier 1997, 48, København, 148-84.

Holmquist H. og Nørregaard J. (1946), Kirkehistorie I, København. Høirup, H. (1983), Fra Døden til Livet, 2. opl., København.

Jürgensen, F. (1969), 89 Tegninger og Gyssebogen, København.

Kindlers Literaturlexikon (1970-1974), Band IC, Werke Ji-Mt, Zürich, 964-965.

Kingo, Thomas (1975), Aandeligt Siunge-Koors Anden Part (1681) i Samlede Skrifter III, København.

Lundgreen-Nielsen, Fl. (1994), "Sjæleøje-Stavnen eller Sjæle-FærgeStavnen”, Grundtvig-Studier 1994, 45, København, 107-121. 
Lundgreen-Nielsen, Fl. (1999), "Grundtvig, Angelsakserne og Sidste Digt", Grundtvig-Studier 1999, 50, København, 208-225.

Michelsen, W. (1956), Den scelsomme Forvandling i N. F. S. Grundtvigs Liv, København.

Michelsen, W. (1995), "Om tankebilledet i Grundtvigs sidste digt", Grundtvig-Studier 1995, bd. 46, København.

Michelsen, W. (1999), "Om tankebilledet i Grundtvigs sidste digt II", Grundtvig-Studier 1999, bd. 50, København.

Noack, B. (1993), “Grundtvigs sidste digt", Vartovbogen 1993, København.

Pedersen, Johs. (1920), "Livets og Dødens Verden" i Israel I-II, København.

Schjørring, J. H. (1987), Grundtvig og Påsken, København.

Schjørrring, J. H. (1990), Grundtvigs billedsprog - og den kirkelige anskuelse, Skrifter udgivet af Grundtvig-Selskabet, bd. XXI, Frederiksberg.

Stevns, M. (1950), Fra Grundtvigs Salmevarksted, København.

Stub, Ambrosius (1961), "Livet som en Seylads" i H. Fonsmark Reitzel, Samlede Digte, 39.

Søe, N. H. (1955), Religionsfilosofi, København.

Thaning K. (1963), Menneske først: Grundtvigs opgør med sig selv, IIII, København.

Thodberg, Chr. et al. (red.) (1983), Grundtvig og grundtvigianismen $i$ nyt lys: hovedtanker og udviklingslinier fra de seneste års grundtvigforskning, Århus.

Thodberg, Chr. (1989), Syn og Sang, København.

Toldberg, H. (1950), Grundtvigs Symbolverden, København.

\section{Noter}

Jeg skylder to redaktionsmedlemmer, Flemming Lundgreen-Nielsen og Kim Arne Pedersen, en stor tak for nyttig og vennesæl hjælp ved konverteringen af et lidt udisciplineret råmanuskript til en afhandling, der i rimelig grad lever op til årbogens formelle krav. Hjælpen har dels bestået i bemærkninger, der har klaret formen uden at forenkle indholdet, dels i henvisninger til litteratur uden for mit egentlige fagområde, men gavnlig til belysning af enkeltheder $\mathrm{i}$ afhandlingen.

Jeg vælger Begtrups titel trods dens antikverede præg. Den rammer digtets særpræg bedre end Uffe Hansens "Afskedskvæde" (Hansen, 1966, III, 341), fordi Grundtvig nok er "kier ad Himmelen", men aldeles ikke "Kied ad Verden", som hans højt respekterede kollega Kingo kunne give udtryk for det (Kingo 1975, 214. Se også DDS-2003 614). Den nyere titel 
"Sidste Digt" er korrekt som kategori, men markerer ikke digtets særpræg i sammenligning med andre "Sidste Digte".

2 De af professor Chr. Thodberg og hans elever udgivne samlinger af Grundtvigs prædikener ( $G P V$ I-IV) rummer sammen med ældre samlinger efter al sandsynlighed yderligere materiale til belysning af dette forhold (se afsnittene "Bibelske billeder" og "Kirkeskibet og Frejs Fartøj”). En inddragelse af dette materiale kunne være nyttig, også i anden sammenhæng, men ville efter min vurdering antage et omfang, der ville overstige grænserne for denne afhandling, hvis undersøgelsen samtidig skulle være af blot nogenlunde tilfredstillende grundighed.

3 Grundtvig bestemmer selv havet som metafor således: "Havet, hvori Himlen spejler sig, udtrykker, i det sande Billed-Sprog, det menneskelige Levneds-Løb i det store, ligesom Floderne i det smaa." (Krønnike-Rim, 3. udg. (1875), 250.)

Gustav Albeck noterer i en gennemgang af nogle udkast fra 1807 til "Egeløkke" og "Havet": "Digteren bekender sin Kærlighed til Havet, fordi det afspejler Tidernes Færd og i sin Vekslen mellem Storm og Stille taler saa kløgtigt til Sindet." (GrSt 1954, 33)

Billedets betydningsvidde viser sig $i$ et par citater. Et alvorligt fra Middelalderen:
Per mare mundanum ruo, naufragus ens sine remo,
Girovagans, in quo vivit sine crimine nemo.
[Bevægende mig i cirkler ror jeg, en skibbruden skabning, uden årer, hen over verdens hav, på hvilket ingen lever uden skyld (min oversættelse)]

Citatet stammer fra Les Lamentationes de Matheolus. publ. par A.G. van Hamel, Paris 1892, Tome 1=Bibl. de l'Ecole des Hautes Etudes. Fasc. 95, her citeret efter Walther 1963-69, 783, nr. 10, og XLII, "Matheolus", $4694 \mathrm{f}$. Se endvidere Kindlers Literaturlexikon, 964-65.

Et mere muntert fra Grundtvigs egen tid, ganske vist tæt knyttet til Københavns topografi, men en prægnant illustration af den hyppigt forekommende humane tilbøjelighed til proportionsforvrængning: "Fa'er! Er det Verdenshavet?" "Nei, lille Gysse, det er Fredriksholms Kanal." (Jürgensen 1969, 166).

Den til havet hørende søfart optræder som eksistensmetafor i den europæiske tankeverden og litteratur lige fra oldtiden. I skibbruddet rummer den momentet af risiko og af krise, man kan gå under i eller komme igennem. Blumenberg, H. 1979, orienterer fyldigt herom og slutter med et kapitel om billedsprogets brugbarhed og begrænsning ved udsagn i erkendelsens grænseregioner.

4 Her, hvor Grundtvig i en salme næsten ordret citerer en bibeltekst, bruger jeg den samtidige oversættelse, angivet ved AO 1740/1819.

Se også $G P V \mathrm{I}, 310-13$.

6 Når Bøye (1998, 130-36), søger at skyde havmotiver fra angelsaksisk litteratur ind mellem Matt 8,23-27, "Stormen på Søen”, og "Bortgangskvæde", str. 2, er det et spørgsmål, om en sådan mellemregning er nød- 
vendig for fortolkning af strofen, i det mindste hvad angår havets farlighed. Den angelsaksiske vinkel er for mig at se en sekundær sproglig nuancering af det bibelske materiale. Den kan så være foranlediget af, at Grundtvig hos angelsakserne har fundet bekræftelse på sin egen tolkning af motivet, et forhold, S. A. J. Bradley strejfede i sin forelæsning: "Before Irenaeus: Grundtvig's Anglo-Saxon Encounter with the 'Oldkirkelige"" på Aarhus Universitet den 6.10.2003. Se det bearbejdede foredrag: "Before Irenaeus: The making of Grundtvig the medievalist" andetsteds i nærværende publikation. Det skal samtidig fremhæves, at S. A. J. Bradley som den egentlige ophavsmand til hypotesen om angelsaksisk påvirkning af Grundtvigs sidste digt har argumenteret omhyggeligt for dette, se Bradley 1993.

7 Afhængigheden af Guds-Ordet som det retvisende kompas møder vi allerede $\mathrm{i}$ afhandlingen "Om Troen og dens indflydelse paa Jordelivet (...)", udgivet og kommenteret i GrSt 1995, 26-74, af Kim Arne Pedersen. Her hedder det s. 47m: "Troen er baade Roer og Ledesteen paa det aandelige Skib og borttages den ganske maatte det blive til Spot for Storm og Bølger , (...)". S. 52m: "En sand Tro er derimod det Eneste, der kan forbinde og vejlede til Maalet (...) Vende vi nu igien Øiet til det Aandeliges Yttringer, da see // (...) vi grandt, hvorledes Troen oplyser som en sikker Ledestierne." Når troen er "sand Tro", dvs. kristen tro, er den uhjælpeligt bundet til Ordet, negativt udtrykt s. 37n: "naar de forlade Christendommen da kaste de Troen, hvo som er af Gud, siger Jesus, hører mit Ord, thi Ordet er ei mit, men Faderens, som mig udsendte, hvo som er af Gud hører Guds Ord, derfor kan I ikke høre mine Ord, fordi I ere ikke af Gud".

Afhandlingen dateres til 1812/13, altså et par år efter "Deilig er den Himmel blaa" (GSV II, 61. DDS-2003 136), hvori Ordet er ledestjerne for vismændene fra Østerland (gennem ørkenen? Se afsnittet "Bibelske billeder") og for os til Jesus. Salmens formuleringer af motivet er nok brede og ikke overvældende præcise, men fællesskabet med B, 1,5-6 og 4,1-2, er åbenlyst.

Ledestenen er en aflang magnetjernsten fæstet til et stykke træ, så den kan flyde på vandet $i$ et fad eller lignende og derved virke som kompas. Den hjalp vikingerne, når der var tåge på Nordatlanten.

Odysséen må have fascineret Grundtvig. I Verdens-Krøniken, 1812, beretter han om den trojanske krig og nævner efter omtale af "Storme" og "Det brede Hav" digtet forud for Iliaden, der nærmest klassificeres som traditionelt mindedigt over de græske helte fra Troja, mens Odysséen kaldes "deilige Sange" (US II, 195-96). Fra cirka 1812 er også hans karakteristik: “(...) den mere idylliske Odyssé (...)” (vel kun delvis; hvad med Polyfemos-episoden?), GrSt 1957, 34.

I Brage-Snak, 1844, kommer han også forholdsvis hurtigt og med en del svinkeærinder om ved Iliaden (US VIII, 717-21), mens Odysséen refereres mere præcist (US VIII, 724-27), igen med relativt udførlig omtale af Fajakernes forunderlige fartøj (s. 725n). Senere tolkes referatet 
"verdenshistorisk" på ganske anderledes indlevet vis end Iliaden (s. 732$35)$.

9 "vilden Strand" og "Bølgen blaa" leder tanken hen på "Blik og Blæst" i A, str. 7, og "Storm og Stille" i Gustav Albecks kommentar i note 4. Der er ikke tale om fuldstændige modsætninger. Det ses af linjerne: "Guds Ærende gaaer hver Storm, / Om den er nok saa vild", fra salmen "Est du modfalden, kiære Ven" (GSV IV, 210, 6. DDS-2003 355). Stilhed er heller ikke nødvendigvis det samme som liv og fred; også døden har sin stilhed. En parallel på landjorden er "Ulve-Graven, svigefuld, / Hvor Blomster gjøgle over Muld" (A, str. 4).

Hvordan bølgen som "blaa" kan rumme risiko, lader sig se af de modstillede strofer 1 og 7 fra digtet "Til Danmark" (Danskeren I, 1848. US IX, 125-26):

Fædreneland!

str.1:

Ved den bølgende Strand

I den maigrønne Lund,

Ved det deilige Sund,

Af de syngende Vover omskyllet,

Midt i Bølgerne blaa

Sidder bleg du i Sorgen indhyllet,

str. 7:

Som paa Afgrundens Rand, (...)

Skal du blomstrende staae,

Med din Mai og med dine

Kiærminder.

Som en Mø med letrødmende

Kinder;

(...)

I strofernes første led skifter omgivelserne karakter. Det idylliske landskab i str. 1 er svigefuldt. Det kan dække over "Afgrundens Rand" i str. 7. I sidste led afsløres det, at døden, der i str. 1 er markeret med "bleg (...) i Sorgen", ikke har det sidste ord. Fædrelandet overtager den, også hvad gloser angår, rige beskrivelse af livet, men intensiveret dels ved overførelsen fra geografi ("Af (...) Vover omskyllet”, str. 1) til historie ("Midt i Bølgerne (...)", str. 7), dels ved skiftet fra omtale til tiltale: "Sidder (...) du" (str. 1), over for: "Skal du (...) staae" (str. 7).

Ud fra denne ledvise modstilling er det rimeligt at se mindst en forskel, måske en modsætning i skiftet fra "syngende" til "blaa" om havet. Mens sangmotivet hos Grundtvig angiver en åben kanal til evigheden (BalslevClausen 1991, 117), kan "blaa" kombineres med et moment af forgængelighed. Forskellige betydningsnuancer kan opsøges i Toldberg (1950), ud fra emneregisteret, s. 318, s.v. Kun i sammenhæng med Himlen og Kiærminderne synes betydningen konsekvent positiv. I forbindelse med havet er farven ud over en fysisk egenskab, der jo er noget forgængeligt, en afglans af Himlen midt i den jordiske ustadighed. Det svarer til, at "blaa" kan betegne skrøbeligheden i vores evne til at 
opfatte det guddommelige, at "Mit Land (...) er Himmel og Jord, / Hvor Kiærlighed boer!", så længe vi lever det kendte liv: "Hvad svagt vi kun skimte, mens Øiet er blaat" (GSV III, 86, 13; Ejnar Thomsen GrSt 1952, $87 \mathrm{~m}$ i anmeldelse af Toldberg (1950).

Høirup (1983) må stadig anses for at være den klassiske fremstilling af dette kompleks hos Grundtvig.

11 Som udgangspunkt for Grundtvigs tale om Mandevid og Verdens Klogskab kan man tage hans egen bestemmelse:

Fornuft og Forstand er indvortes det samme, som Menneske-Haanden med de fem Fingre er udvortes, til at fatte og begribe; saa begge Dele er nødvendige til et kraftigt Menneske-Liv, men kan godt være tomme og paa mangfoldige Maader misbruges til at gjøre baade sig selv og Næsten Skade. (Krønnike-Rim, 3. udg. (1875), 243-44)

Udtrykket Verdens Klogskab er med i 1. udgave fra 1829, hvor det knyttes til det romerske rige som politisk fremgangsmåde. Det sker i digtet "Romermagten" med ordene:

Verdens-Klogskab er mit Navn,

Derfor stræber jeg at knytte

Hele Verdens sande Gavn

Til hver enkelts Egen-Nytte...

(3. udg. 58)

Et eksempel på, hvordan den "paa mangfoldige Maader misbruges", er digtet "Nero", også fra Krønike-Riim (US V, 245-46). [Således 1. udgave, som er kilde her].

Det Mandevid, som omtales i A, og som er renset for politisk præg, er ikke kendetegnet ved misbrug i livet, men ved tomhed, magtesløshed over for døden. Sammenhængen til "Fornuft og Forstand" er tydelig trods det ændrede ordvalg.

I Brage-Snak, 1844, hedder afsnit XVII "Minerva og Heimdal" (US VIII, 677-90). Her taler Grundtvig om "Minervas stygge Nat-Ugle" (s. 682). Heimdal ses som den tro vogter af Bifrost, den bro, der i afsnittet omtales som billede på "ethvert Tungemaal, i Aandens Tjeneste" (s. 688). Uden at råde for livet står Heimdal i dets tjeneste. Ved Ragnaroks komme kan broens vogter slå alarm og være med i modangrebet, men ikke afværge det nederlag, som går forud for verdens fornyelse. Han og Loke dræber hinanden. Toldberg (1950, 167n-168ø) fremhæver, at Heimdals egenskaber: det skarpe syn, den fænomenale hørelse og de strålende talegaver, begrunder tilblivelsen netop i Danmark af "den levende Højskole", jf. US VIII, 685n-68ø.

I sammenhængen her har denne skoles sprog den betydning, at det lader os leve, mens vi er i live her, selv om det ikke kan løse alle livets gåder og ikke kan forhindre afslutningen på livet i den form, vi kender det. Det er som bekendt Grundtvigs modtræk mod den latinske dannelse, som efter hans mening med sit begrebsapparat tager livet af os, før vi dør, og som han knytter til Minerva, i Brage-Snak dramatisk fremstillet som 
forstening af Athene, hendes græske forgænger (US VIII, 677-78). Parallellen til Mandevid og Uglesang i "Bortgangskvæde" er slående. Den første må tie, den anden taler om død som undergang.

Det bør nok nævnes, at i Brage-Snak sammenstilles Loke via "Vittigheden" med Minervas forgænger (US VIII, 665-67 vs. 683-85).

13 Visdomsbegrebet har dybe rødder i europæisk tradition. I en anmeldelse af Kim Arne Pedersen i GrSt 1993, 252-54, af en række artikler af Jørgen Pedersen fremgår det, at denne søger Grundtvig indplaceret i den gren af traditionen, som går tilbage til Augustin. Selv søger jeg med distinktionen mellem Uglesang, Mandevid og Visdom at belyse det forhold, at Grundtvig ser mere end én sproglig tilgang til grænsesituationen.

Ud fra et problem i plangeometrien foreslås følgende sammenligning: Lad "Mandevid" være de gamle ægypteres 3-4-5 trekant, som murere stadig bruger, når de skal afsætte rette vinkler til en bygnings grundmur. "Uglesangen" kan da svare til Pythagoras' læresætning: $\mathrm{a}^{2}+\mathrm{b}^{2}=\mathrm{c}^{2}$, der gælder enhver retvinklet trekant, men samtidig åbner for de irrationale tals problem, der viser sig ved beregningen af en ligesidet, retvinklet trekants hypotenuse, men også bringer undergang over pythagoræernes tro på, at verden afhænger af de rationale tals harmoni, som de baserede på deres forsøg med strengelængdernes forhold til tonehøjder. "Visdom" lignes så ved anerkendelsen af, at der nødvendigvis må bruges omskrivninger, metaforer, symboler, for eksempel kvadratrodstegnet, når summen af katedrenes kvadrater $\mathrm{i}$ en retvinklet trekant ikke bliver et kvadrattal, og hypotenusens længde derfor ikke kan udtrykkes ved et rationalt tal, det vil sige et helt tal eller et decimaltal med et endeligt antal cifre. Alligevel er den en virkelig størrelse.

Udelades undtagelsesvis Uglesangen, kan forholdet mellem Mandevid og Visdom efter min opfattelse også illustreres ved et nutidigt eksempel fra naturvidenskaben. Ud fra sin barndoms betagelse af den funklende stjernehimmel over skovene ved Frijsenborg i Østjylland har fysikeren Jens Martin Knudsen gennem et helt liv engageret søgt at opklare lidt af universets gåde ved hjælp af spørgsmålet: hvordan? Alligevel ønsker han i nederste hjørne af sin gravsten anbragt et: hvorfor? - et spørgsmål, hvis svar kræver et andet sprog end det naturvidenskabelige (refereret efter fjernsynsudsendelsen "Jens Martin Knudsen - en ildsjæl” på DR2 den 15.5.2004).

I den kristne forkyndelses kontekst kan opmærksomheden over for spændingen mellem det, der skal siges, og måden, det skal siges på, betegnes som det særegne ved "den Visdom (...), / Som Ydmyghed er Sjælen i, / Hvorved ei Hovmod hefter". Ud fra, at ydmygheden hos Grundtvig ofte knyttes til det kvindelige, yndige, bløde, kan visdommen manifestere sig i bevidstheden om spændingen mellem modersmål og evangelium og om, at spændingen kan konverteres til drivkraft:

Modermaalet dybt sig bøier,

Let og liflig det sig føier

Efter fremmed Tanke-Gang,

Yndigt selv, og blødt derefter, 
Laaner Aand og Ild og Kræfter

Det af Zions Helte-Sang!

(GSV I, 24, 11. DDS-2003 286)

Den praktiske variant er det mentale slid, der skal til for at formindske den fare, at forkyndelsen forkvakler alt fra banale betragtninger over moralske opskrifter og tør troslære til ren agitation, fordi forkynderen selvsagt er bundet op på både talekunstens regler, menneskelivets vilkår, eftertankens nødvendighed og egne anskuelser.

Uden for Grundtvigs arbejdsfelt vil ydmygheden svare til komplementariteten mellem den agtelse og den taknemmelighed, der hos såvel den øvede amatør som hos den brilliante virtuos er det nødvendige udgangspunkt og i bedste fald det lykkelige resultat af udvist omhu over for nodebilledet i for eksempel temaet fra 1. sats af Mozarts klaversonate i ADur, KV 331, som begge parter på hver sit niveau har mulighed for at udføre med udbytte, - sådan som både barnet og den belæste kan tage plads i fortællingen om Vandringen på Søen.

At analoge holdninger er påkrævede, hvis en teoretisk/kritisk tilgang til tilværelsen ikke skal blive til tom begrebskonstruktion (tør man nævne den såkaldte Kapital-Logik?) og en praktisk/ureflekteret holdning til hverdagslivet til principløs pragmatisme (tør man tale om tremmekalve og burhøns?), er vel også en overvejelse værd.

Hvis Evighedens Port er en kontrafaktur, som Sjæle-Færgen er det over for Karons Pram, er det mest nærliggende som modpol at tænke på "Helvedes Porte" fra Matt 16,18 (AO 1740/1819; AO 1992: Dødsrigets Porte), så meget mere som modstillingen findes i den angelsaksiske digtning, Grundtvig tog til sit hjerte, og hos ham selv fremgår med stor intensitet af "I Kvæld blev der banket paa Helvedes Port", str. 1, over for str. 19, hvor "Cheruben oplod den forseiglede Dør" til Paradiset (herom mere hos Schjørring 1990, 113-35). Indflydelse fra Dantes Divina Comedia kan heller ikke udelukkes. I 3. sang, v. 6-9, siger Helvedes Port til den rejsende:

Før mig var ikkun af det Skabtes Skare

det Evige til, og jeg skal evig stande:

I, som indtræde, lader Haabet fare.

(Molbechs overs., København 1851-52)

For Grundtvig er Evighedens Port det stik modsatte: indgangen til, ikke afskeden med håbet.

15 Da Grundtvig efter mit skøn tænker på eventyret som genre, ikke et bestemt eventyr, gengiver jeg fortællingen i en illitterær version, jeg husker fra mine unge år. Motivet er ganske givet hentet fra legenden om munken og fuglen, der har sammenhæng med en anden variant af eventyret om den forsvundne brudgom (Hammerich 1993, 17n). Jeg har ikke kunnet fastlå, hvordan legenden/eventyret har levet i dansk tradition. 
Det bibelske udgangspunkt for tidsforståelsen i str. 4 findes langt tilbage i Grundtvigs forfatterskab, - selvfølgelig kunne man sige. I et manuskript fra 12.8.1811 findes denne karakteristiske udformning:

At Gud skabte Verden i sex Dage vil ikke sige, at han gjorde det ene efter det andet, men at det ene lod sig tilsyne efter det Andet, ligesom endnu Dage og Aar løbe frem og forandres for os men ikke for Gud. Derfor siger Skriften ogsaa, at tusinde Aar er for Gud som én Dag, og at Jesus det store Offerlam, som saaes at lide i Tidens Fylde allerede var slagtet før Verdens Grundvold blev lagt.

Citatet findes i Michelsen 1956, 191, hvor der blandt andet henvises til Sl 90, 4 og 1 Pet 1, 18-20. Den samme tidsforståelse dukker op i NyaarsMorgen fra 1824 i slutlinjerne fra str. 46:

Guds Timer og Dage / Gaae frem og tilbage,

Du Jordklimp! Tie stille for Gud!

(US IV, 263)

for øvrigt fra den del af digtet, der henviser til årene 1811-15. Også i GSV møder vi den. Meget markant i "Moses i Ørken" fra 1841:

For dig, han nynner, som Dage kun / Aartusinder er at regne, For Dig som Intet den liden Stund, / Vi aande i Støvets Egne.

(GSV II, 23, 7. Bedre kendt er uddraget fra 1857/64 GSV V, 95.

$D D S-2003713$ )

Michelsen, der inddrager flere bibelsteder, konkluderer: "Gud er evig, tiden kun en menneskelig anskuelsesform". Det er mere Kant end Grundtvig.

I den historiske versfortælling Roskilde-Riim fra 1812-13 bruges Es 35,1. 6-7a, som motto på titelbladet. Rosen, der nævnes i Es 35,1, trækkes ind i byens navn, og bækken, der udspringer i ørkenen (Ez 47,8) og lader roserne spire frem, virker som kontinuitetsfaktor på dobbelt måde. Først ned gennem tiderne, dernæst rundt om Europas fastland og ind gennem Isefjorden. Således sættes den kilde, der har navn efter en hedensk hersker, kong Roer, i sammenhæng med profetens ord. Da vandet $\mathrm{i}$ bækken "ud af Gudsvældet" kom, er kilden nu "døbt til Rosenkilde", "Hellig Korses Rosenkilde" (US II, 436. Se også Toldberg 1950, 200).

Den bastante billedbrug, den ordrige stil og de andre skriftsteder til trods er der, hvad kildemotivet angår, et fællesskab med den overskuelige, sprogligt stramme og indholdstætte salme fra 1850 'ernes slutning. I salmen spejler billedsprog og historiesyn imidlertid hinanden, mens de i versfortællingen kommer til at tære på hinandens kræfter. Guddomshandlingens autoritet svækkes, når de historiske hændelser mister kraft, og den historiske hændelse taber indhold, hvis den ikke acccepteres som guddomshandling. Det skyldes, at tydningen i Roskilde-Riim tilbydes gennem aflæsning af denne handlings påståede konsekvenser, mens det $\mathrm{i}$ salmen er tilliden til Ordet selv, der er tydningens grundlag. 
Den "Rednings-Strøm", der omtales i A, str. 6-7, må også have sin oprindelse i Es 35,6-7a/Ez 47,8-kombinationen.

17 Selv forstår jeg Grundtvigs syn på indstiftelsesordene ud fra hans nadversalmer, tydeligt for eksempel i de første og sidste strofer af "Du er vor Skat, o Jesus sød!” (GSV III, 192, 1-8. 20-23. Jf. DDS-2003 467, 1-5. 6-9. Se også Thodberg, Chr. 1989, 296-324). Bag om Romantik, Ortodoksi og Skolastik synes han at opfange det israelitiske helhedssyn, der i GT sprogligt kombinerer alle menneskets fysiske, psykiske og sociale komponenter. En brugbar isbryder til denne forståelse er stadig Johs. Pedersen Israel I-II 67-134: "Sjælen".

Sprogbrugen er til endnu. I et BBC-program i 1970'erne blev en palæstinenser udspurgt om baggrunden for en flykapring med fatal udgang. Han tog afstand fra metoden, men antog ud fra egen erindring om familiens marker med hvede og vinranker, oliventræer og melonplanter, at et lignende savn kunne være baggrunden. På spørgsmålet: "Hvordan kan dine landsmænd slå uskyldige mennesker ihjel for nogle markers skyld?" lød svaret: "Du må huske, at de marker er vores kød og blod". På dansk svarer denne semitiske udtryksform til, hvad jeg som ung præst hørte fra de efterladte til et ægtepar, der havde glædet sig til deres otium, men døde med kort tids mellemrum i løbet af det første år efter, at de havde afhændet deres ejendom: "Vi må huske, at gården var mors og fars hele liv".

Det er realpræsens, så det batter, men uden den aristoteliske substans/attribut-overbygning, der har redet vesteuropæisk kristendoms nadverlære som en mare siden striden mellem Radbert og Ratramnus ved midten af 800-tallet (Aulén 1946, 102-3).

18 Inspirationen bag "Du er vor Skat, o Jesus sød!" er den latinske hymne "Jesu, dulcis memoria". En gendigtning heraf i Kingos og Pontoppidans salmebøger blev udeladt i Evangelisk-kristelig Psalmebog (1798), og i Monrads forslag, som indgik i Roskilde konvents salmebog, var glæden konverteret til at være vores reaktion over for Gud. Grundtvig genindsætter den som Gudsgave, som den var i hymnen, der sammen med tidligere danske gengivelser kan findes i Malling II, 260-72. DDS medtog 18 strofer af 23, deraf de fire med glædesmotivet (DDS 426, str. 1, 11, 12 og 16). Dette halverede DDS-2003 til ni, så "fryd og fred" (DDS-2003 467,1 ) og "barneglæden" (ibid.. str. 7) er med, mens "evig fryd" og "evig fest" er udgået. Også i GSV I, 370, der gengiver den engelske "Lord Jesus is thy table spread", fremhæver i både str. 1 og str. 4 glædesmotivet, men om glæden er med i det engelske forlæg, er mig ubekendt (GSV VI/1, $113 n$ ).

19 Jens Holger Schjørring (1987 og 1990) har på glimrende vis taget den kirkelige anskuelse op til undersøgelse i sammenhæng med nyere teologi.

Relateres der til pinseprædikenens omtale af "de smaa Højtider": Jul, påske og pinse, er vi hverken tilbage $\mathrm{i}$ adventstidens blomstrende rosengård eller fremme ved pinseliljetidens solstrålende forsommer. Vi spores ind på foråret med påskemorgens grundlæggende, men gådefulde 
tilskikkelse, repræsenteret af den foragtede "Vinter-Blomst [, der] melder Vaar":

Ei i liflig Sommer-Luft

Spired jeg paa Blomster-Stade,

Ei saa fik jeg Rosens Duft,

Ikke Liljens Sølver-Blade;

Under Vinter-Storm og Regn,

Sprang jeg frem i golde Egn,

Ved mit Syn kun den sig fryder,

Som har kiær hvad jeg betyder.

(US III, 439)

William Michelsens formulering, at digtet er "et tankebillede (...) af den eksistentielle situation, ethvert menneske er stillet i over for døden", hvor tilføjelsen "Christus" til navnet Jesus er højdepunktet, den endelige afsløring, kan jeg tilslutte mig. Derimod mener jeg ikke, at hans henvisning til bestemte skriftsteder tilstrækkeligt kan begrunde Grundtvigs tale om, at Paradis "dog" er nær. (Michelsen 1995, 105; 1999, 226).

I Jakobs Drøm i Betel, der også opererer med en åben himmel (1 Mos 28,10-22), er Gud nok nær, men konstellationen forfærdelse/befrielse svarer her til Rudolf Ottos velkendte iagttagelse af, at begge reaktioner samtidigt kan knytte sig til et og samme hellighedsfænomen (Rudolf Otto (1917), Das Heilige. Her efter N. H. Søe (1955), Religionsfilosofi, 103). Den passer derfor ikke til "Bortgangskvæde", hvor gru og glæde har hver sin genstand: dødens trussel og dåbens løfte. Heller ikke Sl 139 svarer helt til sagen. Salmen anser det ganske vist for umuligt at undslippe Gud. Selv i dødsriget og "hvor havet ender" er han nær (v. 7-10), men Michelsen indfører momentet "overalt, hvor mennesker priser Gud" (Michelsen 1999, 226m), og det gælder netop ikke i dødsriget. "Hvem takker dig i dødsriget?" hedder det i Sl 6,6. Nærhedens faktum er der i salme 139, men den flygtende forsøger her, ganske vist forgæves, at undslippe det, mens baggrunden for talen om nærhed i "Bortgangskvæde" ikke er flugt fra nærheden, men frygt for, at den skal glippe.

For Grundtvig slår viden om skriftens ord ikke til. Det er ikke på grund af skriftens omtale, han hævder Guds nærhed under alle vilkår, selv dødens. Det er ud fra forkyndelsens tiltale, navnlig som den personrettes i dåb og nadver. At passager fra skriften så også for ham kan løfte sig ud af bogstavens skruestik og blive personlig tiltale, er en anden sag (se for eksempel Thodberg 1989, 303-4).

I et par strofer Petter Dass lyder det til den menighed, han snart må overlade i sin søns varetægt:

Om I mig skulde savne

Gud er dog i mit stæd.

Han haver mand paa gang,

Der efter mine dage

Skal sjunge Zions Sang. 
Om jeg i dødsens dvale

End tier ganske stil,

Guds hane skal dog gale,

Mens kirken bliver til (...)

(Petter Dass Samlede Verker, 1, Oslo, 1980, 429, uddrag af str. 25-

26; "bliver til" må betyde: "bliver ved med at være til".)

Afskedssituationen og de to digteres reaktion på den kan vel føres tilbage til Paulus' afskedsord i de ældste i Milet (ApG 20,32), men har Grundtvig måske også kendt dette digt? Hans eget er rettet "til mine christelige Medtjenere i Ordet", altså en adressat, der har samme opgave som den unge pastor Dass.

På titelbladet til Udsigt over Verdens-Krøniken, 1817, anfører Grundtvig det græske ordprog: Hæmérai epiloipoí mártyres sofôtatoi. Med en for ham karakteristisk selvrådig gengivelse heraf formulerer han sit historiesyn således: "Hvad Sandhed er, maae Tiden vise" (US III, 652). Bag hans livsholdning ligger ikke den samme bestræbelse på at holde vejen åben for nye muligheder; den bygger på den form for fast overbevisning om kristentroens holdbarhed, som tør vove en fri konfrontation om alle tilværelsens vilkår, også de tungeste, med enhver forkæmper for et åbent menneskesyn. Måske kan det samme ordsprog derfor også lade sig bruge som udtryk for hans krav om at være til i sin egen tilværelse og i sin tydning af den, når det mere ordret oversættes: "De kommende dage er de klogeste vidner". 